\title{
nordon
}

The Nordic region - a step closer to gender balance in research?

Joint Nordic strategies and measures to promote gender balance among researchers in academia 

U nordon 



\section{The Nordic region - a step closer to gender balance in research?}

Joint Nordic strategies and measures to promote gender balance among researchers in academia

Solveig Bergman with assistance from Linda M. Rustad and a Nordic reference group

TemaNord 2013:544 
The Nordic region - a step closer to gender balance in research?

Joint Nordic strategies and measures to promote gender balance among researchers in academia Solveig Bergman with assistance from Linda M. Rustad and a Nordic reference group

ISBN 978-92-893-2568-4

http://dx.doi.org/10.6027/TN2013-544

TemaNord 2013:544

(C) Nordic Council of Ministers 2013

Layout: Hanne Lebech

Cover photo: Colourbox

Copies: 1000

Print: Rosendahls-Schultz Grafisk

Printed in Denmark

This publication has been published with financial support by the Nordic Council of Ministers. However, the contents of this publication do not necessarily reflect the views, policies or recommendations of the Nordic Council of Ministers.

\section{www.norden.org/en/publications}

\section{Nordic co-operation}

Nordic co-operation is one of the world's most extensive forms of regional collaboration, involving Denmark, Finland, Iceland, Norway, Sweden, and the Faroe Islands, Greenland, and Åland.

Nordic co-operation has firm traditions in politics, the economy, and culture. It plays an important role in European and international collaboration, and aims at creating a strong Nordic community in a strong Europe.

Nordic co-operation seeks to safeguard Nordic and regional interests and principles in the global community. Common Nordic values help the region solidify its position as one of the world's most innovative and competitive.

\section{Nordic Council of Ministers}

Ved Stranden 18

DK-1061 Copenhagen $\mathrm{K}$

Phone (+45) 33960200

\section{www.norden.org}




\section{Contents}

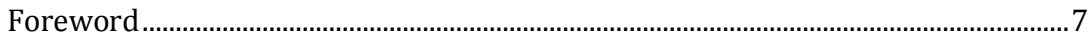

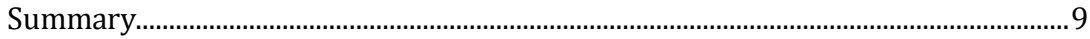

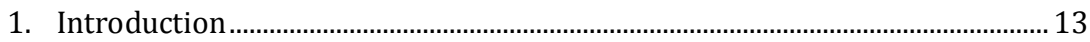

2. Gender segregation in academia in the Nordic region.......................................... 19

3. What action has been taken in the Nordic region to improve the gender balance in academia? ........................................................................................... 23

3.1 National initiatives and instruments ....................................................... 24

3.2 Measures at universities and other institutions of higher education - some good examples ............................................................. 41

4. Nordic research policy challenges in a gender equality perspective .................. 49

4.1 Greater autonomy - challenges and new opportunities .......................... 50

4.2 Excellence in research initiatives - a challenge to gender equality? ....... 51

4.3 Examples of other research policy challenges............................................53

5. Recommendations for future Nordic cooperation ............................................. 57

$5.1 \quad$ Policy development............................................................................... 58

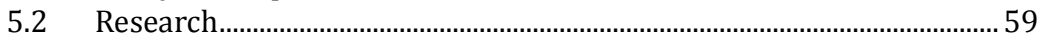

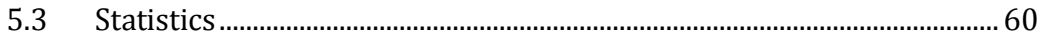

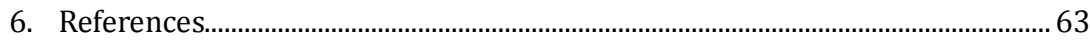

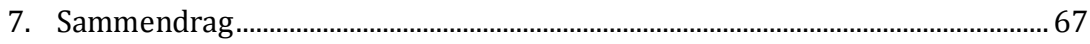

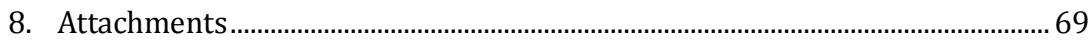





\section{Foreword}

In spring 2011, the Norwegian Ministry of Education and Research invited various Norwegian actors to submit input on the ministry's sector programme in connection with Norway's presidency of the Nordic Council of Ministers in 2012. The Committee for Gender Balance in Research (the KIF Committee) saw this as a good opportunity to highlight the challenges related to gender balance in research facing the Nordic countries, and contacted the ministry. Overall, the Nordic region is known for the progress it has made in achieving equality between women and men. However, 80 per cent of professors in the Nordic region are still men. Compared with the EU-27, this figure is average. We on the KIF Committee believe that the Nordic region should strive to do better than this. The Norwegian presidency decided to focus attention on the strategies and measures that can promote gender balance in research in the Nordic region. The result is this report, and an expert seminar was held by the Ministry of Education and Research on 22-23 November 2012. As of today, there is no pan-Nordic policy or coordinated initiatives on gender balance in research. In this report we make a number of action and policy-oriented recommendations. We encourage Sweden to continue these efforts during its presidency in 2013.

We wish to thank the Research Council of Norway and NordForsk, which have assisted with the design of this project and contributed funding. Both the Nordic Council of Ministers for Education and Research and the Nordic Council of Ministers for Gender Equality have also allocated funding. Others that deserve thanks are KILDEN Information Centre for Gender Research in Norway, which helped with the design of the project and the practical work involved in publication, and the Nordic Institute for Studies in Innovation, Research and Education (NIFU), which supplied the statistics.

At the beginning of the project, a reference group comprised of the fol-

lowing members was appointed: Senior Adviser Lise Christensen of the Research Council of Norway, Director Maria Grönroos of KILDEN Information Centre for Gender Research in Norway, Professor Liisa Husu of 
Örebro University in Sweden, Director of the Department of Research Policy and Analysis Carl Jacobsson at the Swedish Research Council, Senior Adviser Eeva Kaunismaa of the Finnish Ministry of Education and Culture, Adviser at the Icelandic embassy in Brussels Ásgerður Kjartansdóttir, Senior Adviser Unni Nikolaysen of the Norwegian Ministry of Education and Research, Head of Office Helle Poulsen of the Danish Agency for Science, Technology and Innovation, Senior Adviser Lotta Strandberg of NordForsk, Nordic Coordinator Peter Ussing of the Norwegian Ministry of Children, Equality and Social Inclusion, and Senior Adviser Kaja Wendt of the Nordic Institute for Studies in Innovation, Research and Education in Norway. We wish to thank the reference group for its excellent input which, among other things, has helped to ensure the quality of the descriptions of the various countries. Last but not least, we wish to thank Dr Solveig Bergman for taking on the work of preparing the report itself.

Oslo, 19 December 2012

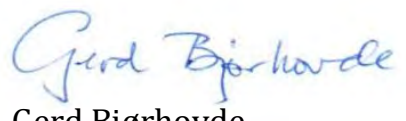

Gerd Bjørhovde

Chair of the KIF Committee

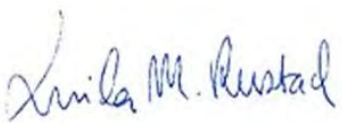

Linda Marie Rustad

Project manager for the report and

Senior Adviser for the KIF Committee 


\section{Summary}

Gender balance in academia is an important research policy issue internationally, which until now has not been addressed or debated at the panNordic level. This report attempts to bring this issue to the forefront by comparing developments on gender equality legislation, statistics and policy in the Nordic countries. The report gives examples of successful instruments and measures that have improved the gender balance in academia in these countries. It presents some relevant research policy issues and challenges in the Nordic region that are important to analyse in a gender and gender equality context.

Currently, about 80 per cent of professors in the Nordic region are men. The gender distribution in the various subject areas is quite skewed, and the greatest imbalance can be found in the natural sciences and technology. The Nordic countries appear in part to follow different strategies to promote gender equality and there are interesting differences between the countries in the gender composition of researchers. There appears to be national differences also in how these issues are prioritised politically and in the degree of political will to control and monitor the gender equality efforts in academia.

The issue of gender equality in academia has been a part of the Nordic research policy agenda longer than in most other European countries, i.e. since the 1970s and 1980s. Many Nordic universities and other institutions of higher education, as well as the national research councils, have been conducting organised gender equality activities and implementing measures to promote gender balance in research for several decades. Focus has shifted from special schemes related to the recruitment of women and individual-oriented measures to the integration of gender equality into the ordinary activities of the institutions through various types of structural and institutional strategies and instruments. The objective in coming years should also be to include a gender equality perspective in all decision-making in academia and in policy development in general. This would be in keeping with the countries' stated 
objectives on the integration and implementation of a gender and gender equality perspective ("gender mainstreaming").

The Nordic research and university policy landscape is in flux, which also has an impact on gender equality efforts in academia. Throughout the 2000s, the centres of excellence and elite research environments have become key instruments in research policy. The strategy is to concentrate more research resources on large units, programmes and elite environments. It is clear that there is a need for more discussion about and research on why the excellence in research initiatives have become an instrument that favours male researchers over their female counterparts, and on what can be done to bring more gender balance to elite environments.

The autonomy reform is one example of a change that may have ramifications for gender equality efforts. In keeping with greater self-governance and autonomy for universities and university colleges, the institutions themselves may have to assume more responsibility for these efforts without the aid of national injunctions, as has traditionally been the case in the Nordic region. These changes in research and university policy must be analysed and evaluated based on the impact of these measures on gender balance in the research community.

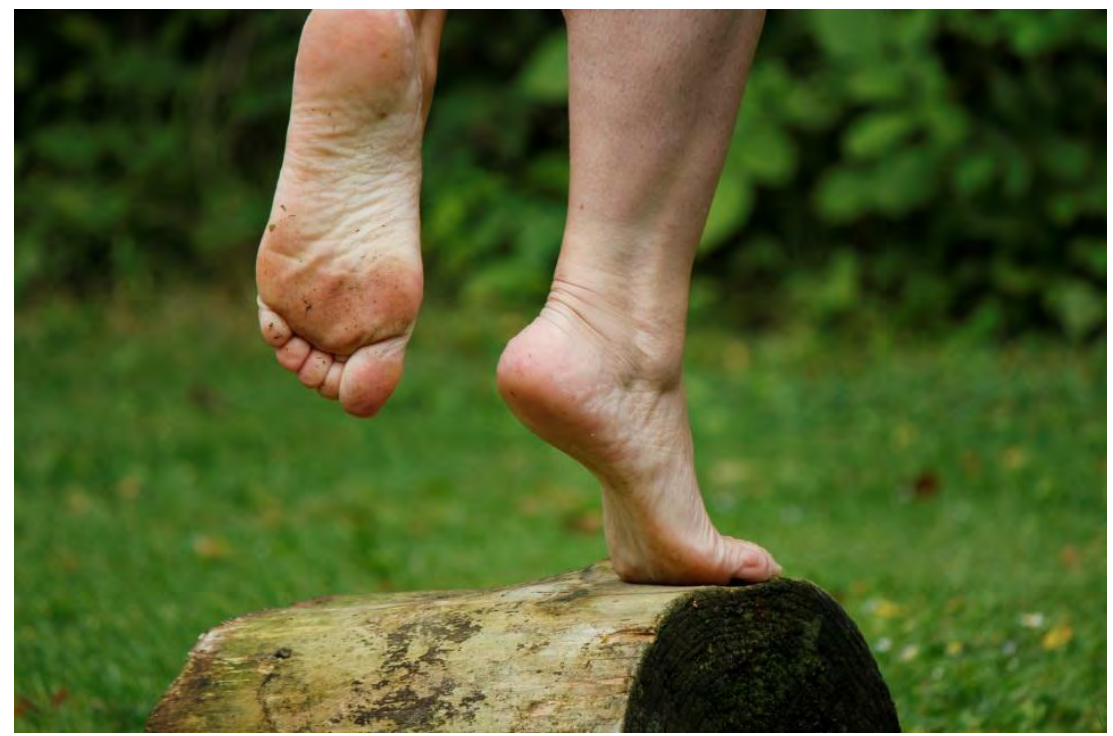

Illustration: www.colourbox.com 
With regard to special initiatives designed to increase the proportion of women in academia, the best examples of this are not necessarily found in the Nordic region. Since the end of the 1990s, the European Commission has put focus on women in research and gender equality issues, and has stressed that gender perspectives in research policy implies more gender equality in academia as well as a change in the content of research. While great attention has been paid to the topic of gender equality and gender balance in academia within the EU, these issues have been almost totally absent from research policy within the Nordic Council of Ministers and in the pan-Nordic research institutions. Nor has Nordic cooperation on gender equality given priority to this field.

Despite the significant differences among Nordic countries, there are very few comparative overviews and comparative studies of gender balance in academia in the Nordic region. Thus there are good reasons to establish and develop Nordic cooperation in this field. The report concludes with a number of recommendations targeted towards decision-makers and other relevant actors within the Nordic Council, the Nordic Council of Ministers and other pan-Nordic institutions that are designed to consolidate the field of gender balance in research into an overall policy and research field in the Nordic countries. These recommendations include the development of a Nordic programme of action that sets specific recruitment targets for toplevel positions in academia, the establishment of a Nordic policy-oriented network, a Nordic research programme and a pilot project on Nordic education and research statistics. 



\section{Introduction}

The Nordic countries are often presented as a "gender equality paradise",1 but the degree of gender balance among researchers in academia does not differ noticeably from that of other European countries. About 80 per cent of professors in the Nordic countries are men. Many subject areas within academia are extremely gender segregated. Progress in the field of gender equality is slow - and has in certain periods been at a complete standstill.

The lack of gender balance within the research community is not only a serious problem for research. It is also a problem for democracy. It goes without saying that women and men should have equal rights and opportunities to conduct research and pursue research as a career. However, gender balance is not only a question of fairness. The credibility and legitimacy of research within society is enhanced when the research community reflects the population as a whole. It should be possible to recruit the most talented individuals to research, regardless of their gender. If the leaders at research institutions are not able to produce, or recruit, the most talented individuals of both genders, the quality of research will suffer. Today the knowledge society, with its increased focus on research, is a major competitive advantage in the development of affluence. Women still represent an underutilised resource in academia. Research benefits when both genders participate and contribute with their expertise, creativity and experience.

However, a more even gender balance entails more than the numerical distribution of each gender across various position categories and subject areas, or the improvement of working conditions, career opportunities and the working environment. Today there is just as much focus on "quali-

\footnotetext{
${ }^{1}$ See e.g. World Economic Forum Gender Gap Reports 2011-2012, which show that the Nordic countries have made more progress on gender equality than other countries.
} 
tative balance" within the research community and in the content and focus of the research activity. While gender equality policy in academia has traditionally focused on "women as the problem", today we see that structures, organisation, culture and leadership within the research community are crucial factors that influence gender balance.

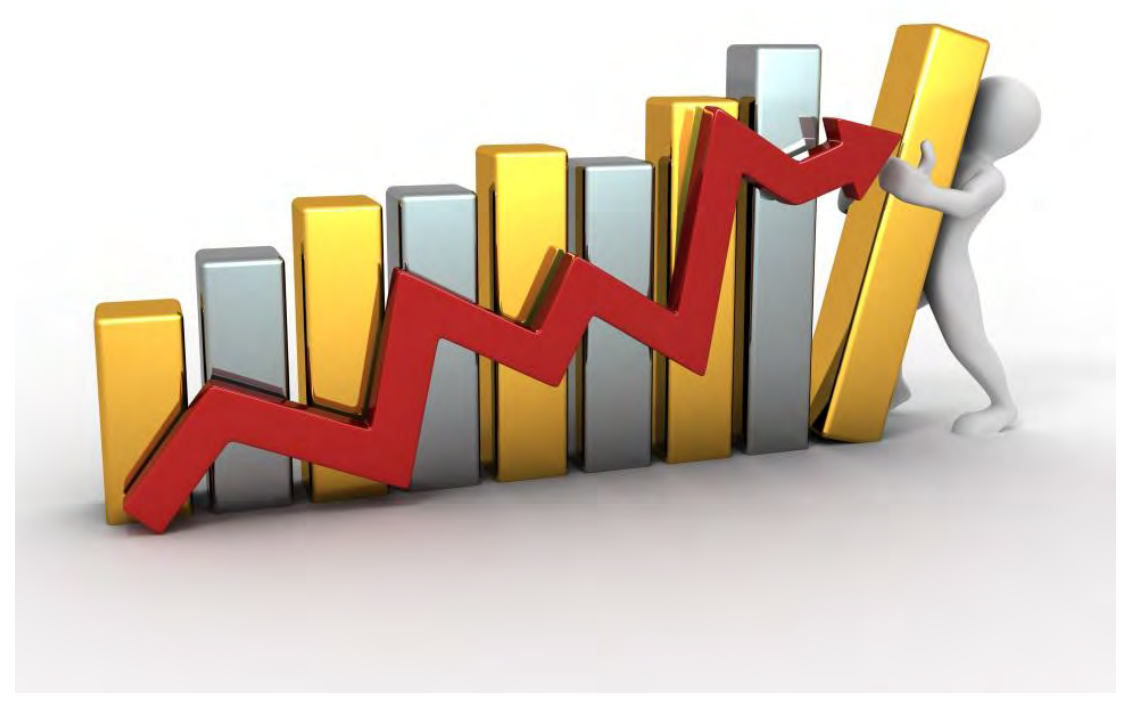

Illustration: iStockphoto.

With regard to special initiatives designed to increase the proportion of women in academia, the best examples of this are not necessarily found in the Nordic region. Since the end of the 1990s, the European Commission has been proactive on issues regarding women/gender in research and has stressed that gender perspectives in research policy implies more gender equality in academia as well as a change in the content of research. In 1999, the European Commission established the Helsinki Group on Women in Science as a meeting place for national representatives from the EU/EEA countries and the Commission. Representatives from the five Nordic coun- 
tries have also participated actively in this group. ${ }^{2}$ In the current strategy on enhancing research cooperation in Europe, the European Commission emphasises gender equality and the integration of gender perspectives in research as key aspects of the EU's new research strategy which are necessary for the establishment of a new European research region. ${ }^{3}$

Since the second half of the 1990s, NIKK, ${ }^{4}$ a transnational resource and information centre on gender research and gender equality in the Nordic countries, has been responsible for implementing Nordic gender equality projects and has also brought attention to research policy issues. In 2001, the topic of gender equality in research was introduced into joint Nordic research policy through a conference entitled "Women in Academia - A Nordic Perspective", organised by the Nordic Academy for Advanced Studies (NorFa) in consultation with the Women and Science Unit under the EU Commission and the above-mentioned Helsinki Group. ${ }^{5}$ Otherwise, and in contrast to the attention paid to gender equality in research by the EU, the topic has not been given priority within pan-Nordic policy on research and gender equality, even though these issues have been on the national agenda in several Nordic countries for a long time. Nor have many comparative overviews or comparative studies of gender equality in academia been carried out in the Nordic region. ${ }^{6}$

With this as background, the report has three main objectives. The first is to compile information about the legislation, state of affairs and policy related to gender balance in academia in the Nordic countries. The second is to shed light on relevant research policy issues and challenges in the

\footnotetext{
2 European Commission 2010a.

${ }^{3}$ See e.g. European Commission 2012.

${ }^{4}$ From 1995 to 2011, NIKK was located at the University of Oslo and operated under the English name of the Nordic Gender Institute (Nordisk institutt for kvinne-og kjønnsforskning from 1995-2005, and Nordisk institutt for kunnskap om kjønn from 2005 to 2011). Beginning in 2013, NIKK will be located at the Swedish Secretariat for Gender Research at the University of Gothenburg.

${ }^{5}$ Nordic Academy for Advanced Studies 2002.

${ }^{6}$ See the special issue on Gender in Academia in the Nordic Journal of Women's Studies (NORA) 3/2001. Ståhle (see SOU 1996: 28) has written a brief description of the gender distribution in academia. More recent publications on this topic include an overview prepared by Husu (2010) for the Delegation for Gender Equality in Higher Education and the Nordic sub-report under the EU project "Meta-analysis of gender and science research" (European Commission, 2010b).
} 
Nordic region that are important to analyse in a gender and gender equality context. The third is to highlight the need for Nordic cooperation on these issues. Thus the report concludes with recommendations designed to consolidate the field of gender balance in research into an overall policy and research field in the Nordic countries.

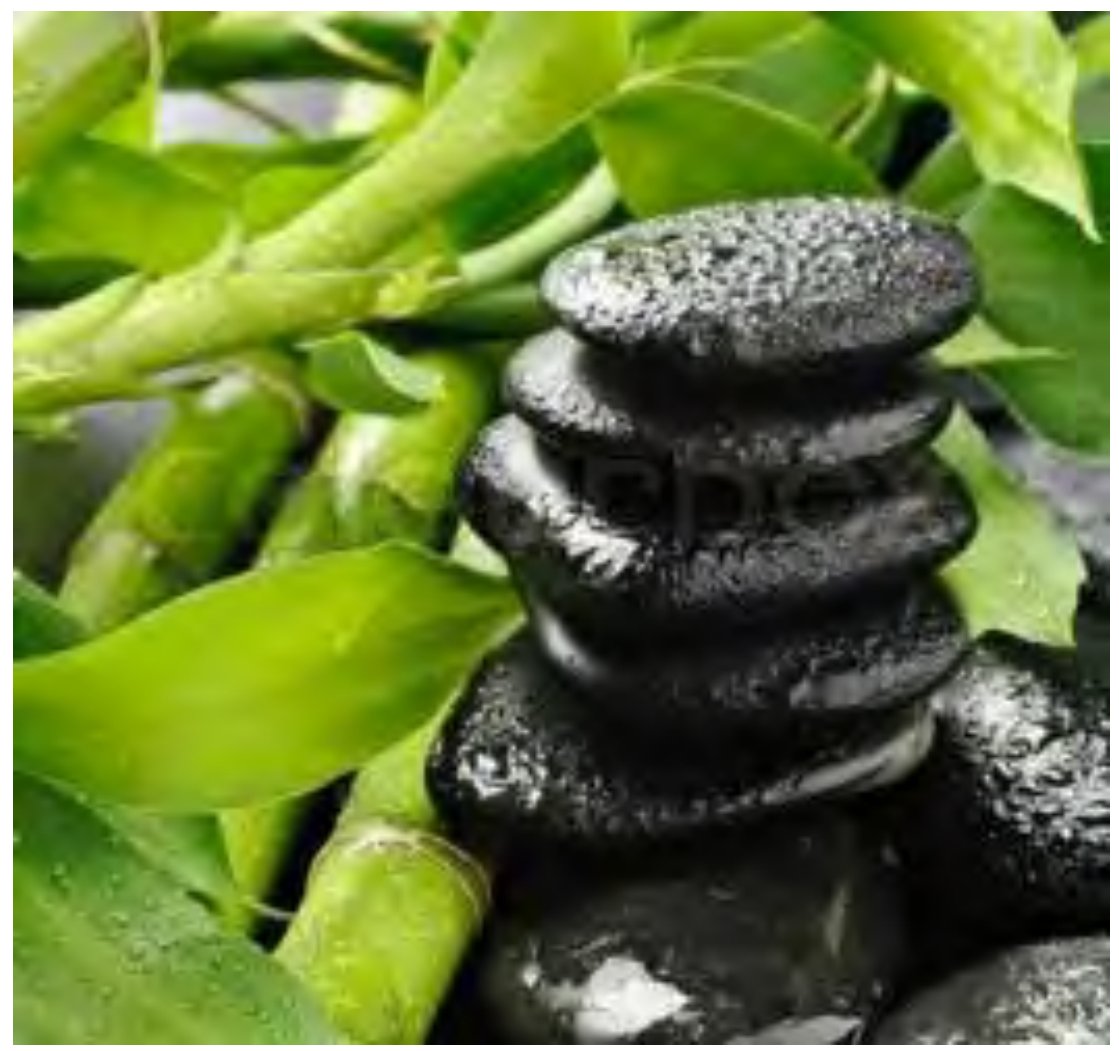

www.colourbox.com

The report is based on a compilation and comparison of statistics and material from overviews, evaluations, research reports and the like, as well as on web-based material from databases, web portals, etc. The report focuses on developments during the 2000s, but it is important to keep in mind that the topic has been on the agenda in the Nordic countries for several decades. 
The umbrella term "academia" is used in this report to refer to higher education institutions - that is, universities and other institutions of higher education. Gender equality measures at the bachelor and master's level are not included, as the focus of the report is on researchers in academia. Another important restriction is that the report does not address the progress made on gender equality at independent research institutes and foundations outside of universities and other institutions of higher education or within research and innovation-based activities conducted by trade and industry. The focus of this report is on instruments that promote gender balance in academia, whereas the discussion of gender research and gender perspectives in research is limited to research related to gender balance in academia.

Due to limited time and resources, it was not possible in this report to present an in-depth analysis of issues regarding gender balance in academia in the Nordic region. For instance, the topic of horizontal segregation - that is, the tendency of women and men to choose different subject areas and disciplines - is mentioned only in passing. Early on there were plans to focus special attention on issues related to mobility, especially across national borders, in a gender and gender equality perspective. Unfortunately this was not possible due to a lack of factual material and research-based knowledge on this issue. However, this is an important topic for future overviews and studies.

Despite these limitations, the report nonetheless provides some good examples of and describes experiences with instruments, measures and research policy topics in the Nordic countries, and can thus be viewed as a call for renewed Nordic cooperation in this field.

Chapter 2 presents a statistical overview of the situation in academia in the Nordic countries based on national statistics, Nordic R\&D statistics $^{7}$ and European statistics. ${ }^{8}$ This chapter also includes a discussion, comparisons and analysis of the status of gender balance in academia in the Nordic region.

${ }^{7}$ http://www.nifu.no

${ }^{8}$ European Commission (She Figures) 2012. 
Chapter 3 contains an overview of national legislation and policy and steering documents in the field, as well as information about how government authorities and institutions cooperate on promoting gender balance in academia. The chapter presents some examples of gender equality measures and initiatives at the local and institutional level that have proved to be particularly successful.

Chapter 4 discusses current key challenges related to research and gender equality policy of relevance for academia in the Nordic countries. Chapter 5 of the report concludes with specific recommendations for future initiatives under the auspices of Nordic cooperation. 


\section{Gender segregation in academia in the Nordic region}

The Nordic research community remains male dominated at the highest level, and the situation does not differ greatly from that in other European countries. Although women comprise the majority of the students who have completed a master's degree and there is relative gender balance among those awarded a doctoral degree, academia does not have the proportion of women expected at the highest level, i.e. among professors.

A "scissors-shaped figure" (Figure 1) has become a classic way of illustrating the proportion of women and men in a typical academic career within various subject areas and countries. This report looks at five levels: at the first level are students up to and including a master's degree, followed by doctoral students (grade D), researchers who have been awarded a doctoral degree, i.e. post-doctoral level (grade $\mathrm{C}$ ), associate professors, etc. (grade B), and full professors (grade A).

Although women's proportion of doctoral degrees and professorships has increased in the past decade in the Nordic region as well as in parts of Europe at large, the career cycle of women and men in the research system still shows gender-specific differences. The Nordic region as a whole shows better figures regarding doctoral degrees than the EU countries on average, but the overall difference between the Nordic countries and the EU-27 with regard to the gender distribution among professors is not very large (Figure 1). 
Figure 1. Proportion of women and men at various rungs of the academic career ladder in the Nordic region in 2010 and the EU-27 in 2010

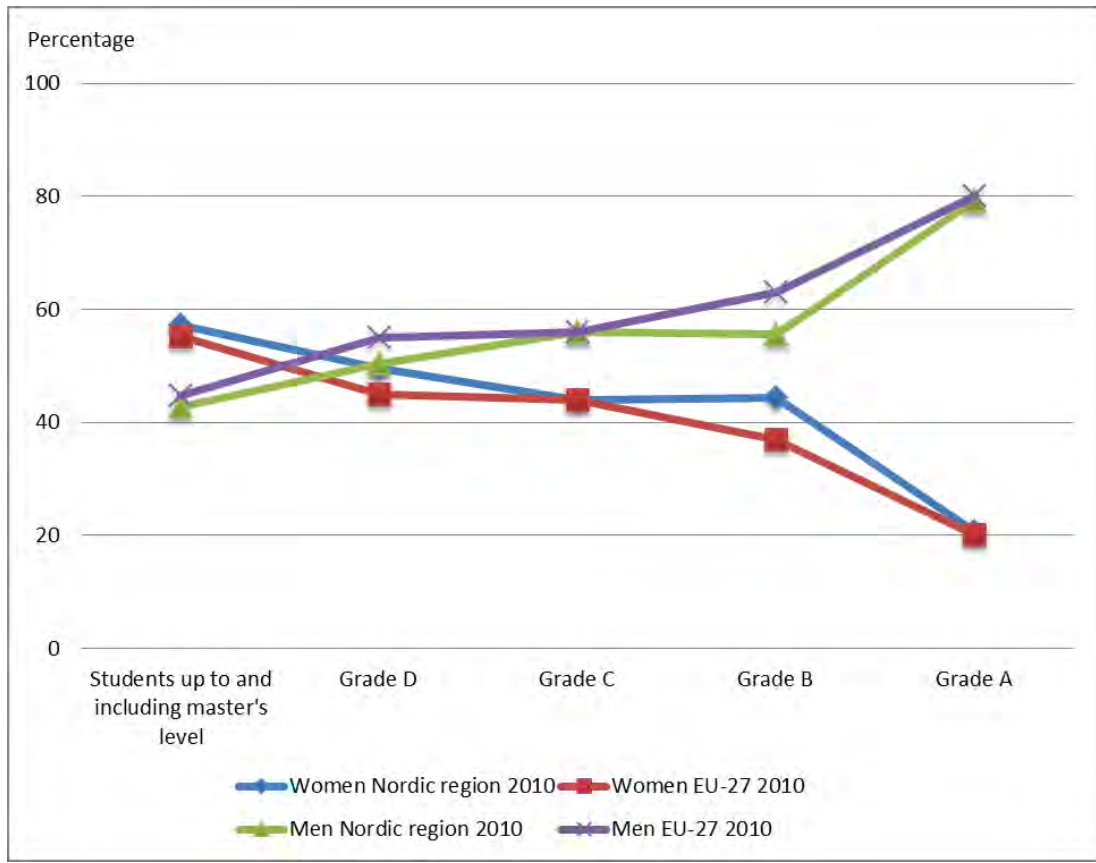

Sources: Nordic Institute for Studies in Innovation, Research and Education (NIFU), She Figures 2012 and national statistics producers.

Corresponding "scissors figures" for the individual Nordic countries are presented in an attachment to this report. The most recent European statistics in She Figures from 2010 show that the proportion of women at the professor level in Iceland and Finland exceeds the EU average (both countries had 24 per cent women, whereas the EU average was 20 per cent). Norway and Sweden have figures similar to the EU average, with 21 per cent women among professors in Norway and 20 per cent in Sweden. In Denmark women comprise 15 per cent of the professors, i.e. below the EU average. With regard to completed doctoral degrees, women in the Nordic countries in 2010 comprised an average of 49 per cent (EU-27: 45 per cent). 
In Finland the majority of those awarded a doctoral degree (53 per cent) were women, and in Sweden the corresponding figure was 50/50. ${ }^{9}$

Figure 2. Completed doctoral degrees by gender and discipline in the Nordic countries in 2010 and the percentage of women at grade A (professor level) in 2010

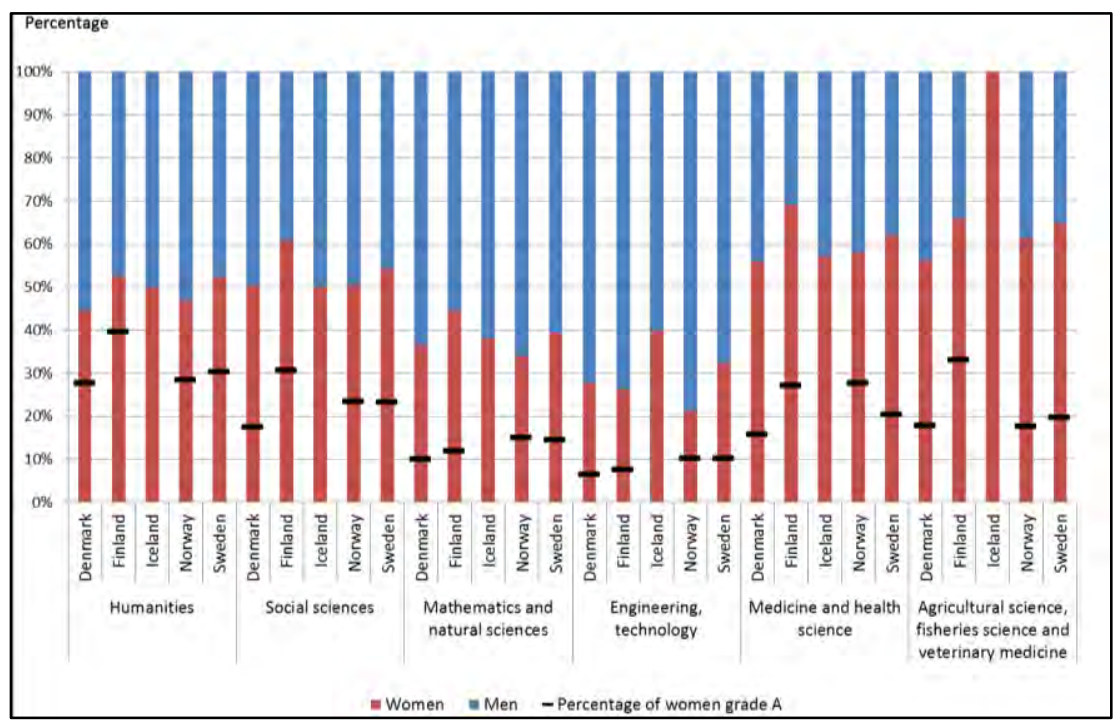

Data by discipline is lacking for Iceland. The percentage of women at grade A is 24 per cent for Iceland.

Source: NORBAL, Eurostat and national statistics producers.

The various subject areas within academia are highly gender segregated at the lower educational levels in all of the Nordic countries, but the gender difference with regard to awarded doctoral degrees in the humanities and social sciences is not very large. The gender difference is more pronounced in technology and the natural sciences, where men are in the clear majority among those awarded a doctoral degree (Figure 2). The proportion of women among professors in the various subject areas does not vary much between the Nordic countries. For years Finland has

${ }^{9}$ European Commission(She Figures) 2012. 
topped the statistics on the proportion of female professors. Figure 2 shows that the proportion of women in the humanities and social sciences is greater in Finland than in the other countries, whereas the proportion of female professors in the natural sciences and technology is lower in Finland than in Norway and Sweden.

The Nordic countries show a more even gender balance than other European countries with regard to leadership in national research councils and institutional leadership in academia. The Nordic countries have more women on the boards of national research councils and among rectors at universities and university colleges compared with other European countries (Table 1). It is important to note here that the provisions on gender quotas for government-appointed bodies (cf. p. 28) have been instrumental in increasing the representation of women on the boards of the national research councils. Danish law does not specify a percentage for the gender distribution of government-appointed bodies, which may explain in part why the proportion of women is lower for the boards of the Danish research councils than in the other Nordic countries. Figures on the gender distribution among rectors show that Norway tops the European statistics (32 per cent of the rectors in 2010 were women), followed by Sweden (27 per cent) and Finland (25 per cent). Denmark lags far behind the other Nordic countries in this area as well (14 per cent of the rectors were women).

Table 1. Percentage of women and men on the research council boards ${ }^{1}$ and rectors at higher education institutions in the Nordic region in 2010

\begin{tabular}{lrrrrrr}
\hline & Board representation & $\begin{array}{r}\text { Ranking in She } \\
\text { Figures }\end{array}$ & Per cent rectors & Ranking in She \\
Figures
\end{tabular}

\footnotetext{
${ }^{1}$ Various research policy councils and research-funding organisations in the countries are included here.

${ }^{2}$ Eurostat's statistics on women in science. Data for the EU-27 and associated countries is included here.
}

Source: She Figures 2012. 


\section{What action has been taken in the Nordic region to improve the gender balance in academia?}

In an international perspective, the Nordic countries became involved in gender equality issues at a relatively early stage, both generally and in education and research policy. Since the 1980s, the Nordic countries have implemented a variety of different types of measures aimed at improving the gender balance in academia. Gender equality measures have been implemented within the education and research sectors, in national research councils, and at universities, university colleges and independent research institutes. These measures have focused on improving the gender balance in specific subject areas, position categories and institutions or in academia and the research sector in general.

Two aspects of gender equality efforts in academia are unique to the Nordic countries. First, statistics on education and research in the Nordic region have been broken down by gender since the 1980s - and even earlier in some countries - which has been crucial for developing adequate data on the gender equality measures in academia. Secondly, gender equality in academia has developed into a separate policy area, often in the wake of or parallel with the public research funding for women's studies and gender research. This research has helped to set the agenda for gender equality policy in academia and produce a knowledge base for the field.

This knowledge base is essential for developing targeted, policyoriented measures and for analysing how research policy can result in gender bias, and thus have unintended effects. Research-based knowledge is also needed to be able to conduct a critical analysis of the academic organisations in a gender perspective. It is nonetheless important to clari- 
fy the boundaries between instruments designed to promote gender balance in academia on the one hand and those aimed at facilitating the application of gender perspectives in research on the other. The focus of this report is on instruments to promote gender balance in academia.

\subsection{National initiatives and instruments}

This section discusses the legal, institutional and organisational structures underlying the gender equality field at the national level in the Nordic countries, the degree to which the higher education and research sectors are encompassed by the countries' gender equality and anti-discrimination laws, and the extent to which the countries' legislation relating to universities and university colleges address gender equality issues. Then an overview is presented of key policy measures and programmes initiated by government authorities to promote gender balance in research. Examples are also given of the actions taken by the Nordic national research councils and the joint Nordic institution NordForsk to address gender balance.

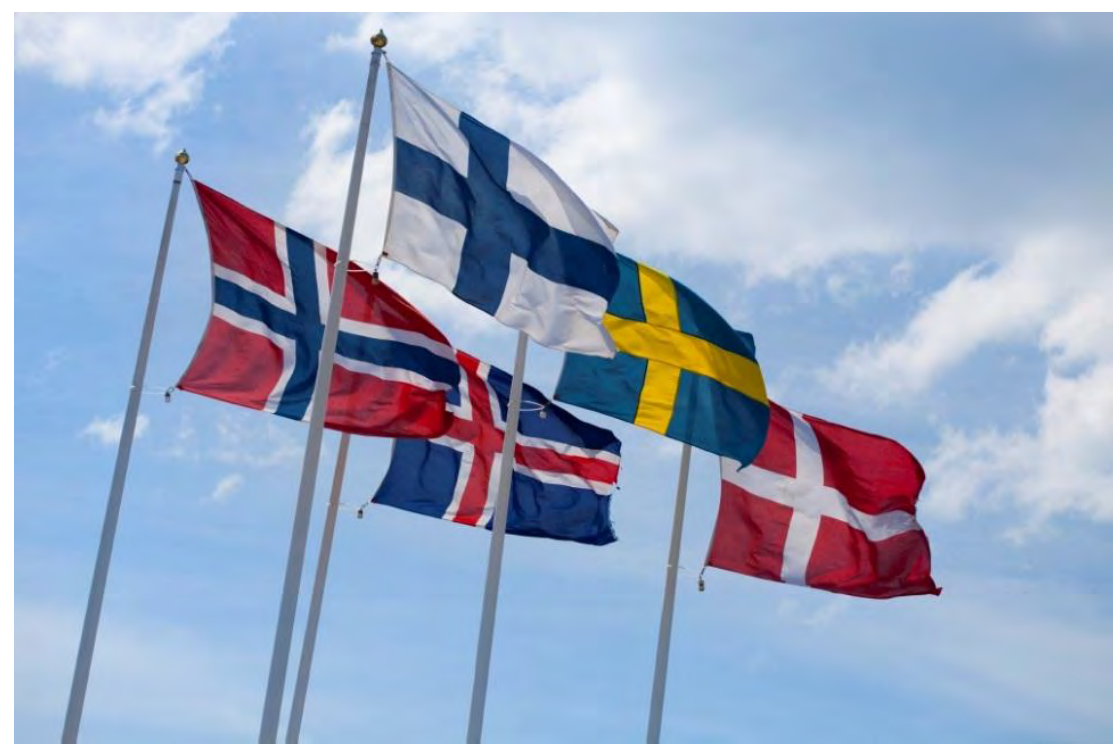

Illustration: iStockphoto. 


\subsubsection{The legal framework}

The Nordic countries were some of the first to enact legislation and establish government enforcement mechanisms in the field of gender equality. The first gender equality laws and national action plans or programmes were introduced in the 1970s and 1980s, and separate administrative mechanisms and systems to promote gender equality were established in all of the Nordic countries (Bergqvist et al. 1999). Gender equality and antidiscrimination legislation ${ }^{10}$ forms the legal basis for the gender equality activities and measures carried out at Nordic universities and university colleges. In all the Nordic countries, this legislation prohibits discrimination on the basis of gender in working life and within the educational system and contains provisions requiring government authorities, e.g. through their educational institutions, to promote equality between women and men. The laws include provisions and requirements on the implementation of measures that educational institutions and employers must comply with as a means of promoting gender equality. This may involve the requirement that educational institutions and workplaces conduct activities, submit reports and draw up action plans for gender equality.

Provisions of this type are significant for universities and university colleges and for the national research councils as well. Denmark, Finland, Iceland and Sweden have laws requiring all workplaces over a certain size to draw up action plans for gender equality. In Norway, public institutions must submit reports on the progress made on gender equality and describe planned gender equality measures. The Norwegian Ministry of Education and Research has required the universities and university colleges to draw up action plans for gender equality. However, the degree to which these institutions, as well as the national research councils, have prepared such plans varies between and within the countries. Moreover, there is variation in the degree to which these plans are actually implemented.

\footnotetext{
${ }^{10}$ Current legislation encompassing gender equality in all the Nordic countries has been supplemented with legislation that includes several different types of discrimination - based on gender, ethnicity, age, sexual orientation, reduced functionality, etc.
} 
Explicit mention of the role of the universities and other institutions of higher education in promoting gender equality is only found in the Norwegian and Swedish acts relating to universities and university colleges and in the Swedish directive governing higher education institutions. In addition, legislation in these two countries requires that hiring committees for university lecturers and professors must include both women and men.

During the 1990s and up until the early 2000s, the practice of earmarking academic positions, including professorships, as a gender equality measure was hotly debated in Norway and Sweden. Many viewed such earmarking as controversial, and it proved to be difficult to implement for legal as well as political reasons. In Norway, the scheme was discontinued and the legislation amended following a ruling by the EFTA Surveillance Authority in 2003. In Sweden, the scheme was also discontinued following a similar ruling by the EU authorities. Until 2011, however, the Swedish directive governing higher education institutions allowed the practice of favouring the underrepresented gender when it was aimed at creating a more even gender distribution in academia. During the 2000s, the scheme was used primarily to increase the proportion of men in femaledominated educational programmes. This practice is no longer allowed, and the Swedish directive has recently been amended.

Today in practice only the use of moderate gender quotas, also referred to as preferential treatment of the underrepresented gender, is allowed when hiring for positions in academia in Norway or Sweden (cf. Section 3a of the Norwegian Gender Equality Act and Section 2.1 of the Swedish Discrimination Act). In Sweden, the Discrimination Act allows moderate preferential treatment of the underrepresented gender if this is regarded as promoting gender equality and if it does not conflict with EU regulations. In Norway, this principle is set out in Section 21 of the Basic Agreement, where it is stated that if there are several applicants for a government position with roughly equal qualifications, the applicants from the gender that has less than 40 per cent of the employees in the relevant position category must be given preference for the position.

Denmark, Finland and Iceland have never practiced radical gender quotas or earmarking of positions in academia for women or the underrepresented gender. According to the Equality Act in Finland and the Act on Equal Status and Equal Rights of Women and Men in Iceland, dif- 
ferent and temporary treatment of the genders that is in accordance with the legislation's aim to promote gender equality is allowed. Like the Norwegian and Swedish legislation, this means that moderate preferential treatment of the underrepresented gender, such as for hiring in academia, does not conflict with the legislation. However, it is difficult to know the degree to which moderate gender quotas or preferential treatment is practiced, as no systematic overviews have been compiled in any of the countries. Some universities and university colleges mention the possibility of using moderate preferential treatment in their action plans. For example, the University of Helsinki's plan for equality and equal treatment states that "Preferential treatment may be used if there are men and women in the applicant pool with the same expertise or with only insignificant differences in qualifications and the underrepresented gender comprises less than 40 per cent of the group" (Section 5.1).

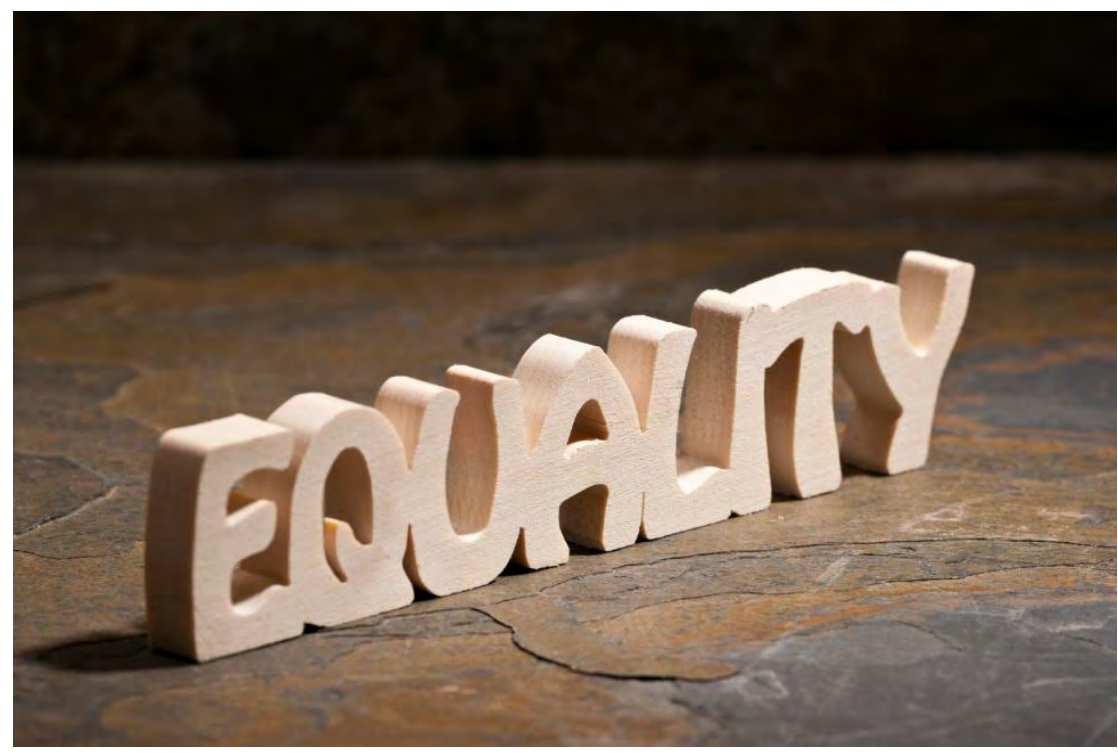

Illustration: iStockphoto.

In Denmark, gender equality legislation does not allow the use of preferential treatment in principle, but it is possible to apply for dispensation from the law if an institution wishes to promote equality between the genders by 
implementing measures that can be expected to favour one gender over the other one. Universities are also eligible to apply for dispensation.

On the other hand, legally established gender quotas have been introduced in several Nordic countries for government-appointed bodies, i.e. boards, councils, committees, etc. ${ }^{11}$ Such quota schemes have had a major impact on the gender composition of the national research councils and the universities' appointed bodies. In Norway, a quota scheme was included in the Gender Equality Act as early as 1981, and the scheme was made more stringent in 1988 when a requirement that at least 40 per cent of both genders had to be represented in government-appointed bodies was introduced. Finland introduced a similar quota scheme, i.e. for at least 40 per cent of the underrepresented gender, in its Equality Act in 1995. Iceland's Act on Equal Status and Equal Rights of Women and Men requires that an effort be made to achieve the most even gender distribution possible on national and municipal councils, as well as on other bodies. In 2008, a provision was introduced requiring at least 40 per cent representation of the underrepresented gender on such bodies. The Danish Act on Gender Equality requires a balanced gender composition on government councils and committees, but it does not specify a percentage distribution between women and men. In 2009, a provision was introduced into the Danish law which allows a minister to keep a seat on a council or committee vacant if candidates of both genders are not nominated. Sweden's Discrimination Act - like the previous Gender Equality Act - primarily encompasses the private sector and does not address gender quotas for government councils and committees. In practice, however, the principle of gender balance (at least 40 per cent representation of the underrepresented gender) on various government-appointed bodies is followed in Sweden as well.

11 Niskanen \& Nyberg 2010, 34-35. 


\subsubsection{National measures}

The way in which national governments and ministries prioritise and organise their gender equality measures has an enormous impact on the effort to promote gender equality in academia. The political signals, requirements and steering from government authorities have been crucial in most of the Nordic countries. In keeping with greater self-governance and autonomy for universities and university colleges, the institutions themselves may have to assume more responsibility for this effort without the aid of national injunctions, as has traditionally been the case in the Nordic region.

However, those ministries with responsibility for research and education and for gender equality ${ }^{12}$ remain key players in gender equality policy and measures in academia, also at the institutional level. Now that research policy and innovation policy are increasingly being linked together, the ministries responsible for trade and innovation will also be important players in the future efforts to promote gender balance in research.

Universities and other institutions of higher education in all the Nordic countries are required to have a system for management-by-objectives, which the authorities use to exercise control over the institutions. In Finland, gender equality is included in the management-by-objectives processes between the ministry and the universities. Moreover, a guideline stating the importance of promoting gender-equal research careers has been included in the new university agreements in Finland. In Norway, the Ministry of Education and Research has addressed the topic of gender equality in its administrative-level meetings with the universities and university colleges.

The Swedish government has adopted a system of "regulation letters" to universities and university colleges, which among other things stipulate requirements for the institutions regarding recruitment targets for female professors and submission of reports on the progress made on gender equality. As early as 1997, the Swedish national assembly introduced special recruitment targets for the proportion of female professors at universities and university colleges. These targets are set out in the regu-

\footnotetext{
12 Some countries have separate ministries for gender equality, while other countries integrate gender equality into other ministries. All the Nordic countries have ministers who are assigned gender equality as one of their areas of responsibility.
} 
lation letters. The recruitment target for 2012-2015 is that women must comprise a minimum of 36 per cent of the professors appointed.

In Denmark, the Act on Universities was amended in 2011 so that the Ministry of Education and the universities now enter into three-year agreements, known as development contracts. Gender equality may be included in these, but it is not a requirement. For instance, the University of Southern Denmark has included gender equality in its contract for 2012-2014.

Governments and central authorities in several Nordic countries have been proactive and implemented important policy measures and national programmes aimed at promoting gender equality in academia. By far the most comprehensive policy-oriented measures are the Committee for Gender Balance in Research in Norway (since 2004) and the Delegation for Gender Equality in Higher Education in Sweden (2009-2011).

\section{Committee for Gender Balance in Research}

The Norwegian Ministry of Education and Research has appointed the Committee for Gender Balance in Research to provide support to and give recommendations on measures that can help to integrate gender equality activities at the institutions in the higher education sector and the independent research institute sector. Since 2004, the committee has received an annual allocation of NOK 3 million. The committee, now in its third term, has received excellent feedback from the sector about the vital role it plays as adviser, catalyst and conveyer of knowledge and policy in the field. The committee has initiated a number of activities, including networks for female researchers, dialogue meetings with the leadership at the institutions, and annual conferences and seminars. It also serves the institutions in an advisory capacity. The committee has created the Gender Balance in Research website which publishes news briefs, facts and information about practical resources to improve gender balance in research in Norway and internationally. ${ }^{13}$

13 http://eng.kifinfo.no 


\section{Delegation for Gender Equality in Higher Education}

The Swedish government appointed the Delegation for Gender Equality in Higher Education for the period 2009-2011. The task of the delegation was to promote gender equality in academia. Its mandate included education and research, as well as the organisation of universities and university colleges. Over SEK 47 million was allocated to institutions and other stakeholders for various types of gender equality measures. The delegation compiled overviews of ongoing activities to promote gender equality in academia, initiated surveys, published reports and organised conferences and seminars. ${ }^{14}$

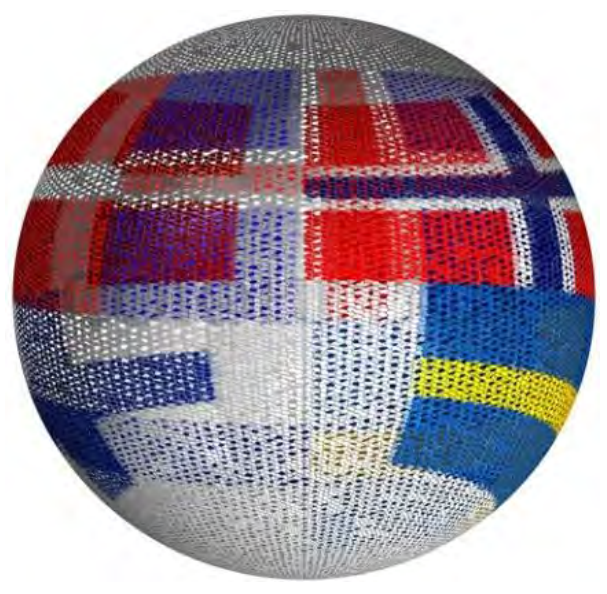

www.colourbox.com

The Swedish National Agency for Higher Education is not a policy measure, but rather a government authority on issues concerning universities and university colleges. However, the agency is mentioned here because since 1999 it has been responsible for monitoring and promoting gender equality at universities and university colleges. The agency has published a number of studies and reports on gender equality in higher education and research, as well as a newsletter on gender equality in higher education. As from 
2013, the Swedish National Agency for Higher Education will be dissolved, and its activities will be incorporated into the new Swedish Council for Higher Education and the Swedish Higher Education Authority. ${ }^{15}$

\section{Other large-scale national programmes and measures}

In addition to these two overarching policy initiatives mentioned above, the governments and ministries in all of the Nordic countries have established other national programmes and measures lasting over several years. These are described in the section below. Except for these initiatives, there are very few national programmes or nationwide measures designed to improve the gender balance in academia in the Nordic countries. Most of the measures are found at the local level, i.e. at the institutions (see Section 3.2).

\section{Denmark}

In Denmark, a number of national initiatives have been launched in recent years to give women a better opportunity to pursue research careers. In 2004, the Minister of Science, Technology and Innovation, together with the Minister for Gender Equality, appointed a "think tank" aimed at recruiting more women to research. In 2006, the group published a report on the topic of increasing the number of women in research. In 2008, the Minister for Gender Equality drew up the Charter for More Women in Management which seeks to strengthen the universities' efforts to reach out to and include talented individuals of both genders. This charter has been signed by several Danish universities, which have also pledged to work towards better gender balance at their institutions. In 2009, the Ministry of Science, Technology and Innovation compiled an overview of gender equality measures implemented in the Danish research community. ${ }^{16}$

In the Report 2009/Perspective and Action Plan 2010 submitted to the Danish national assembly, the Minister for Gender Equality emphasised

\footnotetext{
15 http://www.hv.se

16 Ministry of Science, Technology and Innovation, and the Minister for Gender Equality 2006; Ministry of Science, Technology and Innovation 2009.
} 
the need for greater diversity in research and university leadership. Recruitment of women to high-level research positions is viewed in this document as a vital part of a renewal process which is needed to bolster the strength and competitiveness of Danish research-based activities. ${ }^{17}$

The Minister for Gender Equality and the Minister of Science, Innovation and Technology have also worked together to initiate cooperation with players from higher education and research aimed at encouraging more women to pursue a career in research. As one example, they gathered the leadership of the research institutions and universities for a workshop in 2011 to discuss strategies and measures.

\section{Finland}

Since the 1980s, the Council for Gender Equality (TANE) appointed by the national assembly, especially its research section and later the Subcommittee for Gender and Power, as well as the women's studies coordinator (up until 2001), have worked to promote gender equality in academia. In addition, the Ombudsman for Equality has played a vital role in ensuring the implementation of gender equality legislation at universities and university colleges. Among other things, the Ombudsman has evaluated the plans to promote gender equality at the institutions.

In October 2010, the Finnish government approved a report on equality between the genders which evaluated the government's gender equality policy in the previous decade. The report addresses education and research in detail and emphasises the importance of integrating gender equality issues into Finland's overall science and university policy in the future. ${ }^{18}$

\section{Iceland}

According to a decision taken in the Icelandic national assembly on a fouryear programme of action for gender equality, the Minister of Education, Science and Culture will be responsible for presenting gender equality awards in higher education in Iceland beginning in 2013. The awards will be given to institutions that can show substantial progress on gender equality.

\footnotetext{
17 Minister for Gender Equality 2010.

18 Ministry of Social Affairs and Health 2010.
} 


\section{Norway}

The Ministry of Education and Research has established an incentive scheme that awards extra funding to universities and university colleges which appoint women to permanent academic positions (professor, associate professor) in fields where women are underrepresented, i.e. mathematics, the natural sciences and technology subjects. The three-year trial scheme was launched in 2010, and an extension until the end of 2013 has been proposed. The annual budget framework for the scheme is NOK 10 million, and each appointment triggers a funding award of NOK 300,000. As of today, seven universities and two university colleges participate in the scheme. ${ }^{19}$

The Gender Equality Award has been awarded by the Ministry of Education and Research every year since 2007. The prize of NOK 2 million is presented to universities, university colleges and independent research institutes that have conducted successful gender equality activities at their institutions. ${ }^{20}$

\section{Sweden}

The IDAS (Identification, Development, Advancement and Support) project was a national, overarching leadership development project in Sweden that aimed to increase the number of women in leadership positions at universities and university colleges. ${ }^{21}$ The project was a cooperative effort between several institutions. The IDAS project was highly successful and spawned a number of activities both during the project period and after its conclusion.

Launched in 1999, the project received funding up until 2007, but it still exists today in the form of networking activities. During its most active phase (2004-2007), the IDAS project had approximately SEK 23 million that it used to fund a variety of projects that were implemented throughout the country. The board of the Association of Swedish Higher Education served as the project manager, and the institutions' rectors

\footnotetext{
${ }^{19}$ See e.g. Aukland 2012.

20 Ibid.

$21 \mathrm{http}: / /$ www.idas.se
} 
were responsible for implementation. The IDAS project launched measures such as the establishment of networks (locally, regionally and nationally), competence-building through thematically-oriented seminars, leadership development programmes, mentoring programmes (locally and nationally), surveys and reports, etc.

VINNMER (2007-2014) is a programme launched by the Swedish Governmental Agency for Innovation Systems (VINNOVA) under the Ministry of Enterprise, Energy and Communications, whose task is to promote innovation and development. The aim of the VINNMER programme is to create better career opportunities for female researchers within strategically important research areas. Special emphasis is placed on women's opportunities to reach the highest levels of research. Since 2007, about 100 female researchers with completed doctoral degrees have been given the opportunity to pursue additional qualifications. The total budget for the initiative is about SEK 500 million (roughly SEK 600 million if EU funding is included). VINNOVA provides funding for up to half of a researcher's salary for three years, while the employer provides the remainder. The VINNMER programme consists of two parts: cooperation with international research and innovation environments and cooperation between Swedish research environments. Mobility programmes are being established between academia, companies and research institutes in Sweden and between Swedish and international institutions. ${ }^{22}$

\subsubsection{Gender equality measures at the national research councils and NordForsk}

The Nordic national research councils provide funding for researcher positions, research projects and research infrastructure at universities and university colleges. The gender equality measures implemented by the research councils may thus have an impact on the gender balance in academia. It is therefore relevant to take a closer look at the national research councils' gender equality efforts and measures.

22 http://vinnova.se/VINNMER 


\section{Denmark}

In 2006-2008, the Danish Council for Independent Research (DFF) established a measure targeted towards female researchers within technical and natural science subjects. Younger female researchers and postdoctoral research fellows were eligible to apply for these grants. Moreover, the DFF allocated DKK 43 million in 2008 to promote female research managers. In 2009, the DFF allocated an additional DKK 70 million for this same purpose. These grants were awarded to female researchers who wanted to gain experience with research management, which is a requirement for qualifying for a professorship. In 2010, the Danish Council for Independent Research consolidated all of its initiatives targeted towards female researchers into a new research career programme called Sapere Aude. One of the programme's objectives is to encourage more female researchers to pursue a career in research management. It is also worth mentioning that the DFF has decided that "gender in research" will be the theme of its annual members' conference in 2013.

In 2008, the Danish Council for Strategic Research (DSF) introduced a requirement that both genders must be represented on the steering groups of "strategic research centres" and "strategic research alliances" (two key instruments established by DSF) that seek research funding. This requirement is mentioned in the calls for proposals, but there has been no evaluation of the instrument to date.

In 2008, a research group in Denmark studied how the Danish research councils had allocated funding in 2001-2008 from a gender perspective. ${ }^{23}$ The researchers found clear signs that women had been systematically treated in a disadvantageous manner in the allocation of research funding. The researchers showed that women had an overall lower success rate than men in the Danish Council for Independent Research, although this varied within the various subject areas. Moreover, women were awarded smaller funding amounts on average. In the Danish Council for Strategic Research, women had a markedly lower success rate, but were on the other hand awarded larger funding amounts than their male colleagues.

${ }^{23}$ Andersen \& Henningsen 2009. 


\section{Finland}

The Academy of Finland, the national research council institution, has been a major player in gender equality policy in academia since the $1980 \mathrm{~s}$, and it launched its first gender equality plan in the early 2000s. A stated objective in the performance target agreement between the Ministry of Education and Culture and the Academy of Finland is that research careers will be made more attractive for women and that women's career opportunities in research will be expanded. The current gender equality plan (2011-2013) contains a specific target to increase the proportion of the underrepresented gender to a minimum of 40 per cent when researcher positions are filled by the Academy of Finland. As a concrete measure for improving women's opportunities to be recruited to highlevel researcher positions, the President of the Academy of Finland asked the scientific research councils in 2008 to follow the principles in the gender equality plan when nominating candidates for these positions. The proportion of women holding prestigious academy professorships, for example, rose from 13 per cent (2009) to 22 per cent (2010).

The provisions in the Act on Equality Between Women and Men on gender quotas have been applied to the board and the various scientific expert committees of the Academy of Finland since 1995. The proportion of women on these bodies was 50 per cent in 2010. Funding periods must not be shortened due to parental leave, and funding for research stays abroad must be increased by 20 per cent if researchers take their children with them outside the country.

\section{Iceland}

Iceland's Ministry of Education, Science and Culture has decided that as from 2012 all foundations and funds that allocate research funding must systematically compile information about the gender distribution on scientific evaluation committees, including those seeking research funding and those who are awarded funding. In 2013, the ministry will evaluate how both genders have benefited from the research funding. The Icelandic Centre for Research (RANNIS), which funds and administers research, is subject to this requirement. 


\section{Norway}

In 2007, the Research Council of Norway adopted a new Policy on Gender Equality and Gender Perspectives in Research (2007-2013). The plan is followed up by means of ongoing action plans. ${ }^{24}$

The Research Council is required by the Ministry of Education and Research to submit reports on gender distribution along a number of indicators. The Research Council's criteria for the assessment of grant applications include the recruitment of women, gender balance in the projects and gender dimension in the research activity. The Research Council of Norway has introduced marking of its projects for both gender balance and gender perspectives in research. This is a measure that will provide a better basis for reporting on these areas.

In 2013, the Research Council will launch the new Gender Balance in Senior Positions and Research Management (BALANSE) initiative which will provide support to and strengthen the efforts of the research institutions and research environments in this area, in part through grants for career-promoting measures for researchers and for the development of leadership and organisational culture at the institutions. The initiative will also help to develop research-based knowledge in the field. In 2012, two surveys were conducted for the BALANSE initiative. ${ }^{25}$ The BALANSE initiative has received NOK 7 million in earmarked allocations from the national budget for 2013. The total budget framework for the first call for proposals in 2013 is NOK 15 million and the estimated total budget (2013-2017) is a minimum of NOK 58 million.

\section{Sweden}

The Swedish Research Council, the Swedish Council for Working Life and Social Research (FAS), the Swedish Research Council for Environment, Agricultural Sciences and Spatial Planning (Formas) and the Swedish Governmental Agency for Innovation Systems (VINNOVA) have provisions in their regulations that they must promote equality between the genders

\footnotetext{
${ }^{24}$ Research Council of Norway 2007.

25 Aukland 2012; Vabø et al. 2012. For information on the BALANSE initiative, see http://www.forskningsradet.no
} 
and submit regular reports on their activities from a gender equality perspective. The research councils in Sweden, especially the Swedish Research Council, compile overviews at regular intervals of how the research funding has been distributed by subject area and gender. ${ }^{26}$

According to the Swedish Research Council's Strategy for Gender Equality (2010-2012), the Council seeks to "achieve and maintain an equal gender distribution in its evaluation panels," which is interpreted to mean that the underrepresented gender must comprise 40 per cent of the members of evaluation committees. The Swedish Research Council is also charged with ensuring that the proportion of women and men among those seeking research funding corresponds with the proportion of women and men among those researchers who could potentially seek funding. In addition, it is the Council's task to ensure that the level of allocations to women and men is roughly equal and that women and men are awarded the same funding amounts on average, taking into account the nature of the research and form of support. This is followed up every year through special reporting. 27

According to its regulations, VINNOVA must work to promote both gender perspectives in research and gender equality within its area of activity. The distribution of research funding in a gender equality perspective has also been important for FAS, while Formas has developed guidelines with a gender equality perspective for use in its evaluation committees. Furthermore, the Swedish Research Council, FAS, Formas and VINNOVA have established a joint working group that discusses the allocation of research funding to women and men and how gender equality can best be promoted.

It can also be mentioned in this context that the Swedish government's recent proposition for research and innovation allocates SEK 32 million (2013-2014) to VINNOVA for research on improving gender equality at universities and university colleges, in trade and industry, and in the public sector.

\footnotetext{
26 For more information, see the European Commission 2009, 124-126.

27 http://www.vr.se
} 


\section{NordForsk}

NordForsk is an organisation under the Nordic Council of Ministers that provides funding for Nordic research cooperation as well as advice and input on Nordic research policy. ${ }^{28}$ In 2010, NordForsk adopted a proposal that a gender perspective should influence the design of NordForsk's funding instruments and choice of research programmes. For example, NordForsk's Top-level Research Initiative now requires applicants to describe how a gender perspective is incorporated into the project and the organisation of the project's activities.

In 2012, NordForsk and the Secretary General of the Nordic Council of Ministers signed a Memorandum of Understanding with the European Commission. This document emphasises the parties' increased focus on issues related to gender equality and gender perspectives in research..$^{29}$

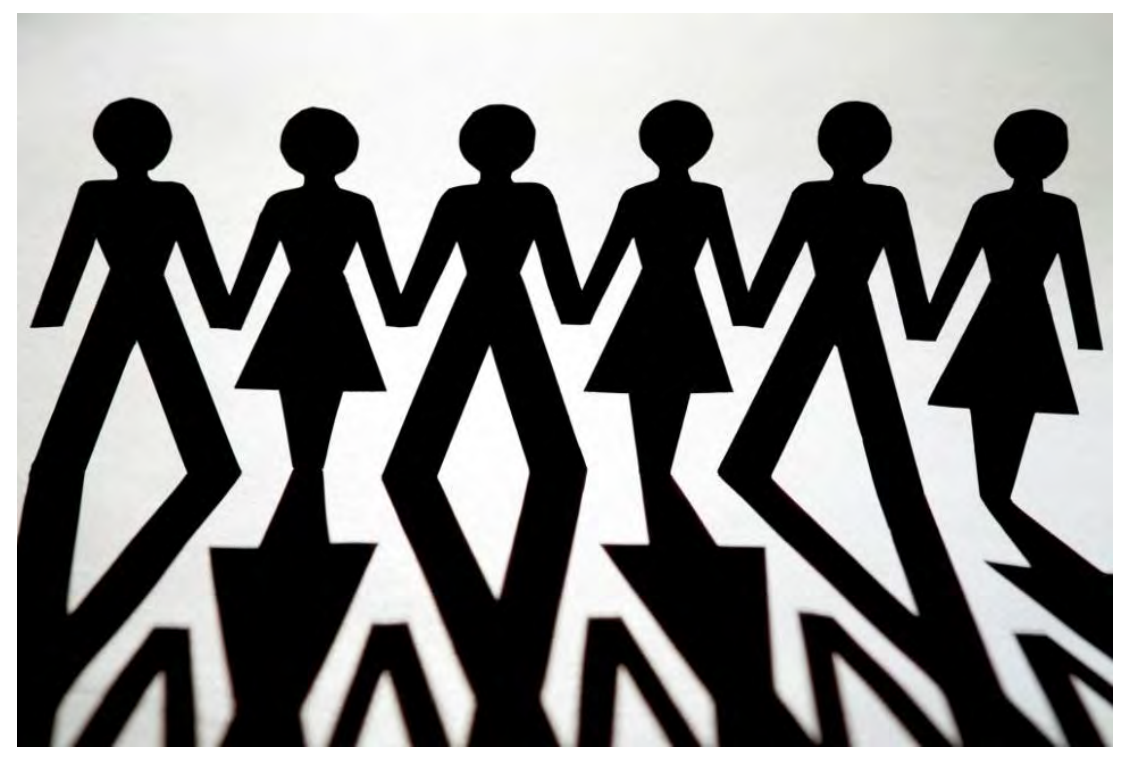

Illustration: iStockphoto.

28 http://www.nordforsk.org

${ }^{29}$ NordForsk magazine 2012, 4-5. 


\subsection{Measures at universities and other institutions of higher education - some good examples}

This section discusses in more detail how gender equality efforts are organised at universities and other institutions of higher education in the Nordic countries as well as the various types of instruments and measures used in recent years to promote gender balance at the institutions. A selection of interesting, successful examples of measures and initiatives at specific institutions in the various Nordic countries are presented, but this does not comprise a comprehensive or exhaustive overview of gender equality measures that have been implemented.

The level of activity and status of gender equality efforts at the institutions vary widely within and between the Nordic countries. A number of different instruments have been used, including both structural strategies aimed at integrating gender equality into the organisation or institution and time-limited measures targeted at specific, clearly-defined problems.

The gender equality activities and measures at universities and university colleges are targeted towards all types of personnel, including students. The latter group is not included in this report, nor are administrative and technical staff at the institutions. The report emphasises activities at the system level as well as individual measures for recruiting the underrepresented gender to permanent academic positions and leadership positions. It is obvious that the institutions face challenges with regard to promoting both women's and men's research careers and to advancing women to leadership positions. They also face challenges related to enhancing the institutional leadership's expertise on gender balance in academia.

Gender equality measures targeted towards the underrepresented gender have become commonplace in recent years. In practice, this means that most of the measures focus primarily on increasing the proportion of women in academia. While the debate has previously dealt with "womenspecific" measures, the language used today is more gender neutral (the "underrepresented gender"; gender balance). At the same time, focus has shifted from special schemes related to the recruitment of women to the integration of gender equality into the ordinary activities of the institutions. In this case, various types of structural and institutional strategies and in- 
struments take on special importance. In practice, the overarching strategies are often combined with more individual-oriented measures.

The following section presents some important, interesting examples from the various Nordic countries - with a view to facilitating an exchange of experience across national borders. The examples are divided into three categories: structural and institutional strategies; recruitment and career development; and working conditions and the family-career combination. ${ }^{30}$

\subsubsection{Structural and institutional strategies}

Strategies that seek to integrate gender equality into the daily activities of universities and universities are the responsibility of the institutional leadership. Expertise on gender equality and gender should therefore be included in general leadership development programmes at the academic institutions. Such expertise should also be used as a criterion in new appointments to leadership positions and in evaluations of leaders.

In Norway, the Committee for Gender Balance in Research visits top-level administrators at universities, university colleges and independent research institutes to discuss the role and responsibility of the institutional leadership in gender equality efforts. In 2010, the committee published the report "Talent at Stake: Changing the Culture of Research - Gender-Sensitive Leadership", ${ }^{31}$ which contains examples of what leaders at various levels in academia can do to improve the gender balance at their institutions.

In addition to general leadership training, there is a need for leadership development for women to encourage them to assume high-level academic positions and other leadership tasks. Some universities, such as the University of Copenhagen, have established such leadership programmes for women. In Sweden, the aim of the national leadership development programme IDAS (see page 34) was to increase the number of women in upper-level academic positions. Since 2004, Lund University has run a leadership programme for women called Akademiska kvinnors ansvar (AKKA)

\footnotetext{
${ }^{30}$ For more detailed overviews of gender equality measures at universities and university colleges in the Nordic countries, see e.g. Aukland 2010; Heikkilä \& Häyrén Weinestål 2010; Husu 2010.

${ }^{31}$ Rustad \& Ericson Ryste 2010.
} 
("Academic Women's Responsibility") whose objective is to increase the number of women in leadership positions at the university, such as deans, vice-deans, department chairs, and members of important committees and commissions. Due to high demand, AKKA will now begin to include male participants.

Today Nordic universities and university colleges are required to draw up their own action plans for equality between the genders and to submit regular reports on their gender equality measures and the results achieved. For instance, the action plans set targets for the proportion of women in the various position categories and outline various types of recruitment strategies and measures to achieve these targets. The institutions' action plans for gender equality may include statistics on the gender distribution at the institutions, both among students and in various personnel categories, as well as gender-divided statistics on applicants, nominees and appointments to academic positions, salary statistics, and information about the distribution of research funding in relation to gender. Gendersensitive statistics are a good steering instrument for gender equality efforts and are relatively well-developed in the Nordic region.

Individual institutions incorporate gender equality into their overall strategic planning efforts. In addition, gender equality may be one aspect of the cooperation and steering agreements that the institutions enter into with the ministries of education and research. Gender budgeting, i.e. the practice of following up budgets and allocations in a gender and gender equality perspective, and other types of gender impact assessments are more recent strategies that are not widely practiced yet in the Nordic countries. One example is found at the University of Oslo, which in 2008 conducted a gender impact assessment on selected budget items at the institution.

Since the 1980s and 1990s, a large percentage of the universities and several of the university colleges in the Nordic region have established gender equality committees or similar bodies. Several institutions - especially in Norway and Sweden - have also established dedicated administrative positions (either full- or part-time) with gender equality as their area of responsibility (sometimes expanded to diversity). Other institutions have given certain individuals in the administration responsibility for gender equality as part of their regular positions or they have organised their gender equality efforts in other ways. 
In Finland, Norway and Sweden, various employees with responsibility for gender equality efforts at universities and other institutions of higher education participate in nationwide networks or organisations. They organise regular national meetings and conferences. Finland has also had a web-based discussion list. European universities began organising gender equality conferences in the early 1990s. These conferences, which bring together researchers as well as practitioners, have been held three times in the Nordic region (Helsinki 1998, Stockholm 2005 and Bergen 2012). The European Network on Gender Equality in Higher Education has a web-based, international discussion list (EQ-UNI), which is owned by the University of Helsinki and currently has more than 500 participants.

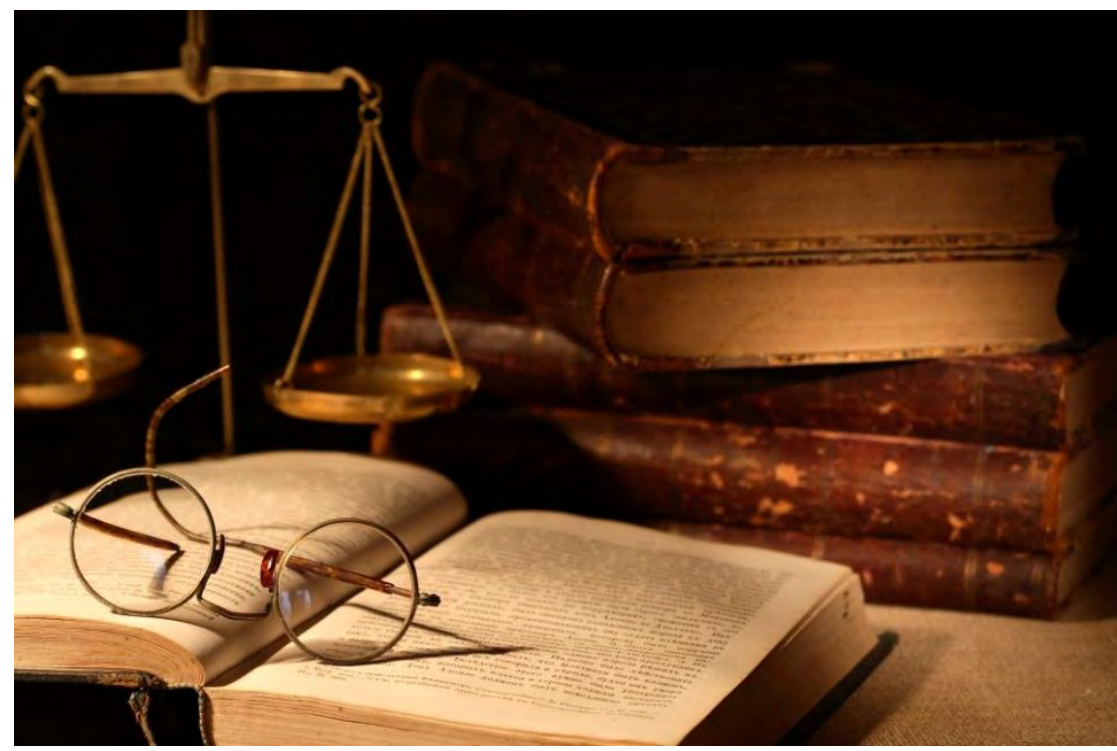

Illustration: www.colourbox.com

\subsubsection{Recruitment and career development}

Some Nordic universities and university colleges have introduced measures as part of their recruitment, employment and personnel policy that take gender equality into account when researchers are hired or when they seek advancement or promotion in their careers. A common measure in all of the countries is that vacancy announcements for academic positions must 
encourage the underrepresented gender, especially women, to apply for the positions. Another widely-practiced measure is that both genders must be represented in various types of decision-making bodies and evaluation committees at the institution.

It is legally permissible in some of the Nordic countries to apply preferential treatment in cases of appointment and promotion, but today the institutions seem reluctant to take advantage of this opportunity. On the other hand, institutions in Denmark, Norway and Sweden have introduced various types of career development measures, which may include aspects that favour or provide compensation for the underrepresented gender. A measure used by many institutions, especially in Norway, is qualifying grants that facilitate career development for women who aspire to professorships. At some institutions the measures apply to the underrepresented gender, while at other institutions, especially in highly gender-segregated fields such as technology, women are favoured within existing legal parameters. The grants may be used as payroll compensation to give women time to complete the research needed to qualify for a professorship, to prepare applications for research funding or to publish academic articles.

A scheme practiced at the Norwegian University of Science and Technology, for example, awards start-up packages - funding for day-to-day expenses, salary and equipment - as a means of supporting women recently appointed to academic positions in their establishment phase. This scheme is restricted to departments that are highly male dominated. The University of Troms $\varnothing$ has established a package of measures to help women to achieve promotions in their research careers. The university's target is to have 30 per cent women in top-level positions in all subject areas by 2013. The initiatives have been successful so far: In 2012, women held 28 per cent of the top-level positions.

Some Norwegian universities and university colleges have set aside central incentive funding to encourage the units to recruit women to professor II positions. ${ }^{32}$ The University of Copenhagen has a similar scheme

\footnotetext{
32 Professor II is a designation used in Norway to refer to professors employed in a part-time position (up to 20 per cent) at an institution other than the institution where the person is employed in his or her main position.
} 
(cf. p. 42). Qualifying grants are also used at several Swedish institutions, such as Stockholm University and Uppsala University.

Several Nordic institutions have established mentoring schemes in which a mentor (an older, experienced researcher, often a professor) serves as an adviser and conversation partner for a talented research fellow or juniorlevel researcher seeking career development. In Norway, the University of Oslo, the University of Bergen, the Norwegian University of Science and Technology and the University of Tromsø have developed their own mentoring programmes for women. An evaluation was recently conducted of the mentoring programme at the University of Oslo. ${ }^{33}$ The evaluation emphasised that the scheme has worked well. In Finland, the University of Helsinki used to have mentoring programmes for academic and administrative staff. These were open to both genders, but most of the participants were women. Subsequently, the university has introduced gender-mixed mentoring programmes for employees in leadership positions.

Several Danish universities have implemented measures to recruit more women to a career in research, e.g. by signing the Gender Equality Minister's Charter for More Women in Management which seeks to strengthen the universities' efforts to reach out to and include talented individuals of both genders. Aarhus University has appointed a task force headed by the director that is charged with preparing a talent development strategy. The University of Copenhagen has established the Freja programme at the Faculty of Science which aims to increase recruitment to post-doctoral research positions. Women in particular are encouraged to apply.

In 2008, the University of Copenhagen approved an action plan entitled "Diversity at the University - More Women in Research and Leadership" for the period 2008-2013, which seeks to improve women's career opportunities at the university. The plan has three parts: financial rewards for faculties and departments that appoint women professors; internationalisation scholarships for junior researchers of the underrepresented gender; and talent and leadership development, including mentoring programmes. The university was granted a dispensation from the Act

${ }^{33}$ Løvbak \& Holter 2012. 
on Equal Treatment of Men and Women in order to implement the action plan. The plan does not entail favouring women or using gender quotas, but the purpose is nonetheless to increase the number of qualified women applicants to professorships. The action plan has had a positive impact on the proportion of women among newly appointed professors.

\subsubsection{Working conditions and the family-career combination}

Gender-sensitive measures aimed at improving researchers' working conditions and overall job satisfaction can be developed locally within the units. For example, it is possible to look at how the distribution of teaching and administrative tasks versus research functions for women and men and how the work at the institution could be structured differently. A new time-use study of academic employees at universities and university colleges in Norway shows that male researchers without children work the most hours, while women with children work the fewest. The study also shows that women feel more insecure than men regarding their control over their work situation. However, perhaps most importantly, the survey shows that much of the research production is carried out in the evenings. One of the conclusions of the report is that career competition takes place after the work day is over. ${ }^{34}$ Gender equality legislation in all of the Nordic countries gives educational institutions and workplaces responsibility for preventing and inhibiting sexual harassment. This problem exists also in academia, but it remains a taboo topic, both hidden and under-researched. A 2008 survey of doctoral students in Sweden found that 9 per cent of the women and 2 per cent of the men said they had been sexually harassed in academia. ${ }^{35}$ Some Swedish universities, including Uppsala University and Stockholm University, have provided training to their employees about ways to prevent sexual harassment, and these issues are addressed in various forums, such as performance reviews and employee surveys. In

\footnotetext{
34 Egeland \& Bergene 2012.

35 Swedish National Agency for Higher Education 2008.
} 
Finland, several universities have compiled overviews of sexual harassment, and institutions such as the University of Helsinki have included issues related to sexual harassment and other forms of unwelcome behaviour in their staff and leadership training.

The Nordic welfare states provide far more support to those who combine family with career than many other countries do. Despite this, it is important to implement measures in academia that ease or compensate for the burdens by creating a framework in which researchers with small children can continue to develop their academic careers. For example, Finland and Sweden have introduced a scheme that gives research fellows and other temporarily employed researchers the right to an extended fixed-term contract when they take parental leave. 


\section{Nordic research policy challenges in a gender equality perspective}

Today the research and university policy landscape is under significant pressure to change. Among the new challenges are the trend towards autonomy in academia, the excellence in research initiatives, innovation policy and internationalisation. As a result of these new research policy focus areas, the gender equality efforts in academia have become more diverse and complex in recent years. Although gender equality is a stated objective in academia in the Nordic countries, there are very few comprehensive studies of university and research policy in a gender equality perspective. The intention exists, however. For instance, the Finnish government's gender equality programme for 2012-2015 states that the overall objective is to include the issues that concern women's research careers and gender equality in all science and university policy. ${ }^{36} \mathrm{~A}$ common challenge is to incorporate a gender equality perspective in new areas and instruments that are introduced to strengthen research, whether these comprise excellence in research initiatives, innovation or internationalisation.

Gender equality efforts in academia are also affected by changes in national and international gender equality policy, such as the multidimensional and intersectional approach to gender equality and gender mainstreaming policy. This chapter explores some of the current challenges already mentioned as examples of topics that must be analysed in a

${ }^{36}$ Ministry of Social Affairs and Health 2010: 9. 
gender equality and gender perspective and that are important to discuss in a joint Nordic context.

\subsection{Greater autonomy - challenges and new opportunities}

In recent decades a wave of reforms of the higher education sector has swept through Europe, including the Nordic region. In several countries the legal status of the institutions has changed, which has given them more financial and administrative independence than previously. This has resulted in changes in the management and administrative structures at universities and university colleges. Reforms that increase the autonomy of the universities have been introduced or planned in all of the Nordic countries.

At a time when central government control is being decreased, it is vital to find new ways of carrying on a dialogue between the central government authorities, such as the ministries, and the universities and university colleges. Among other things, it is important that gender equality is integrated into the agreements entered into between the ministries and the institutions. Before introducing reforms or new research policy strategies or measures, an analysis should be conducted of the ramifications of these for gender equality. Along with greater autonomy, the institutional leadership will assume a more prominent role than previously. This means that the leadership must take even more definitive action and be proactive with regard to gender equality policy at their institutions. To achieve this in an effective manner, there is a need to provide training to both academic and administrative leaders on problems related to gender balance and gender equality in research. This has developed into a separate field of knowledge, which it is crucial that leaders are aware of and that becomes an integral part of the exercise of leadership in academia. 


\subsection{Excellence in research initiatives - a challenge to gender equality?}

Throughout the 2000s, the centres of excellence and elite research environments have become key instruments in research and university policy internationally, including in all of the Nordic countries. The strategy is to concentrate more research resources on large units, programmes and elite environments. In particular, the top-level leadership at the centres of excellence in all of the Nordic countries is highly male dominated (see Table 2).

Table 2. Gender distribution of the leadership at Nordic centres of excellence in 2011, percentage

\begin{tabular}{lcccrr}
\hline Gender of centre leadership $^{1}$ & Denmark & Finland & Norway & Sweden & Total \\
\hline Women & 7 & 19 & 13 & 8 & 12 \\
Both women and men & & & & 3 & 1 \\
Men & 93 & 81 & 87 & 89 & 87 \\
$N$ & 68 & 75 & 46 & 73 & 269 \\
Not included $^{2}$ & 3 & & & 15 & \\
\hline
\end{tabular}

${ }^{1}$ Gender of the centre director, or the most recent director of discontinued centres.

${ }^{2}$ Centres without identifiable leaders. Includes centres that were not launched or that do not have a website or web page with information about the leadership.

Source: Nordic Institute for Studies in Innovation, Research and Education (NIFU) 2012.

A few analyses have been conducted of the ramifications of the excellence in research initiatives for gender equality. All of these analyses were carried out after the schemes were introduced. A Danish study of the research councils' distribution of funding in a gender perspective found indications that a gender imbalance was especially noticeable when selective and highly visible instruments were used. The success rate was somewhat lower for women in the EliteForsk programme. ${ }^{37}$

In 2009, the Research Council of Norway conducted a survey of the Outstanding Young Investigators scheme (YFF), the Centres of Excellence scheme (SFF) and the Centres for Research-based Innovation scheme (SFI). The report entitled "Gender equality in research - what works?"

${ }^{37}$ Anderson \& Henningsen 2009. 
compares the calls for proposals and grant allocations for the three schemes in the period 2001-2006. The report concludes that clarifying the expectations of the applicants and taking gender equality into account in the application process may have a positive impact on the gender distribution of the applicants and those selected to receive funding. ${ }^{38}$

A Swedish study, commissioned by the Delegation for Gender Equality in Higher Education, ${ }^{39}$ investigated women's and men's chances of receiving funding from the excellence in research programmes during the 2000s compared with their scientific productivity. According to the study, over 87 per cent of this funding was allocated to men. Of the 20 researchers who received the largest share of the excellence in research funding, 19 were men. The conclusion of the researchers was unambiguous and direct: "The progress on gender equality achieved in research in the latter part of the 1990s has largely been wiped out" (p. 10). According to the study, ten years of excellence in research policy in Swedish research funding has had serious negative consequences for gender equality in academia.

On the basis of these studies, it is clear there is a need for more discussion about why the excellence in research initiatives have become an instrument that primarily benefits male researchers to such a great extent and what can be done to bring more gender balance to elite environments. It also appears that these initiatives have so far avoided an analysis of the measures they themselves have planned to initiate to improve gender equality.

The EU has placed the debate about concrete gender equality initiatives in excellence in research programmes and the problem of quality criteria high on the agenda. The European Commission focused attention on the gender-related ramifications of the excellence in research initiatives and the definition of scientific excellence as early as $2004^{40}$ and established the expert group "Gender and Excellence", which studied research funding in 33 European countries in a gender perspective (EU 2008). There is good reason to raise the issue of quality criteria and excellence in research in the Nordic countries and at the joint Nordic level as well.

\footnotetext{
38 Norwegian Research Council 2009.

39 Sandström et al. 2010.

${ }^{40}$ European Commission 2004.
} 


\subsection{Examples of other research policy challenges}

\section{Innovation and research policy}

Today innovation is a major research policy trend that needs to be discussed in a gender equality perspective. The individual institutions, the research councils and the national authorities bear a responsibility for the formulation of research and innovation policy.

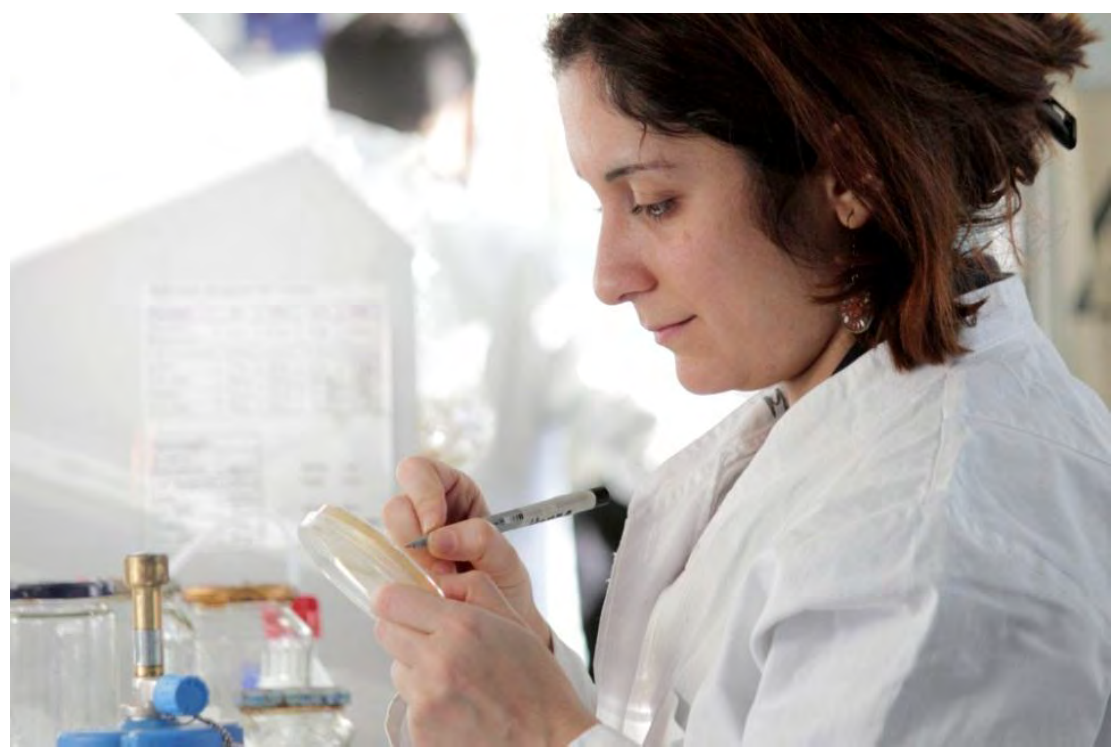

Illustration: Science Photo Library / NTB scanpix.

Like elsewhere in Europe, innovation is a common element in research today. The term "innovation" is increasingly used in research policy to mean not only product and quality development, but also service innovations, the use of new technologies, more innovative use of public resources, etc. Thus innovation is defined in relatively broad terms. At the same time, women are clearly in the minority in the most traditional innovation processes (technology transfer). ${ }^{41}$ It is therefore important to dis-

41 Vabø \& Ramberg 2009. 
cuss the effect on gender equality when research and innovation become so tightly intertwined. The shift towards innovation may also create strong pressure on the priorities within the social sciences and humanities, i.e. disciplines where women are strongly represented.

\section{Internationalisation of research}

Today international research cooperation and greater mobility are regarded as essential for the development of a person's career research. It is crucial to look at any gender-based differences in researchers' international cooperation activity and mobility across national borders and at their participation in international networks. It is also significant to analyse the measures and incentives used to promote internationalisation in the various Nordic countries and to assess the degree to which these measures and incentives create equal opportunities for women and men to develop their research careers. A Norwegian study has shown that female researchers participate less than their male counterparts in international research cooperation. ${ }^{42}$ The link between international researcher networks and career development is interesting in a gender equality perspective and should be studied more closely. The knowledge base - both research and statistics - in this field must be developed. ${ }^{43}$

Internationalisation also entails the recruitment of international researchers to the Nordic countries. A key objective in this context should be to facilitate the recruitment of outstanding female researchers from abroad. Those responsible for recruitment should be encouraged to actively seek out women across national borders in subject areas where the Nordic countries have few women.

\footnotetext{
42 Ibid.

43 Very few empirical studies of mobility patterns in academia have been conducted to date. A Norwegian study has investigated the mobility pattern of doctoral students. According to this study, there are few gender differences in the international mobility of this group or among male and female students with caregiving duties (see SIU 2011).
} 


\section{Gender mainstreaming and multi-dimensional gender equality efforts}

The efforts to improve the gender balance in academia are affected by changes in the gender equality policy landscape in the Nordic region. Today all of the Nordic countries are expected to adopt gender mainstreaming as an overall gender equality strategy. This strategy entails integrating and incorporating gender equality efforts at the institutional leadership level so that gender equality is not a separate area of specialisation, but rather an area that permeates decision-making at all tiers of the institution.

The EU has long emphasised that gender equality in research must be implemented through a mainstreaming strategy in general research policy. A shift in gender equality efforts in academia has occurred in the Nordic region, and as already mentioned, the focus has been redirected from viewing female researchers as the problem to examining the research system and the way research is structured. The objective of the current gender equality efforts in academia is primarily to change the structural conditions that create inequalities and to use instruments that integrate gender equality in order to achieve the institution's other objectives. Thus gender mainstreaming is the strategic approach to gender equality taken today.

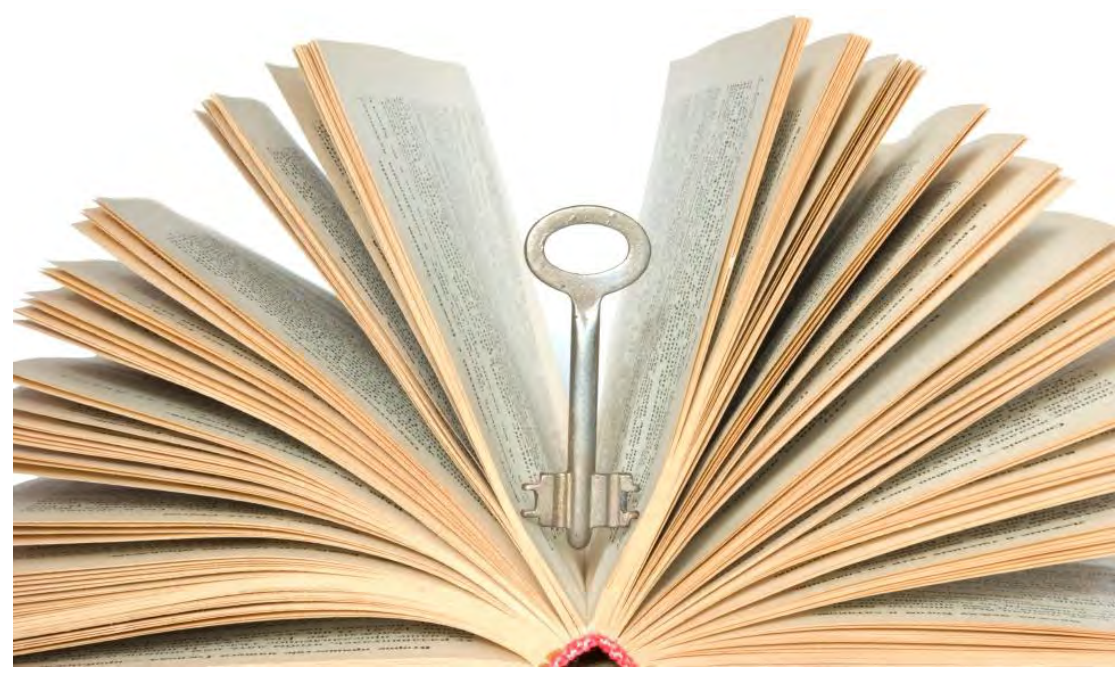

www.colourbox.com 
The mainstreaming strategy has been criticised because in practice it has led to an abdication of responsibility, consigning the goal of gender balance to rhetoric and theory. ${ }^{44}$ The institutions that succeed with this strategy have a leadership team which ensures there are sufficient resources, both in terms of staff and budget, to implement the strategy. Someone must have operational responsibility for implementing the strategy. Combining a mainstreaming strategy with specific measures gives a boost to the efforts and helps the institutions to reach their research policy objectives more quickly.

\section{Other forms of discrimination}

A final current challenge for gender equality efforts in Nordic academia is that equality today often entails more than gender. This is partly a result of international developments and harmonising anti-discrimination legislation, as well as an emphasis on intersectionality. Discrimination on the basis of ethnicity, sexual orientation, age and functionality must also be combated. The laws in the Nordic countries have been amended, and new groups have been given protection against discrimination. Efforts extending across these categories, which explore how the various forms of discrimination meet and interact, have assumed a prominent place in this picture. Several Nordic universities and other institutions of higher education have decided to adopt a broader concept of equality in their future efforts. Others fear that such a broad focus may lead to a "watering down" of the efforts to promote gender equality. It is too early to determine the extent to which a broader concept of equality promotes or inhibits gender equality efforts, but this development should be followed up and evaluated.

${ }^{44}$ See e.g. NOU 2011: 18. 


\section{Recommendations for future Nordic cooperation}

The report shows that despite an increase in the proportion of female researchers in the Nordic countries, the gender distribution in higher level academic positions in particular remains disproportionately unbalanced and the various subject areas highly gender segregated. There are interesting differences between the Nordic countries in the gender composition of researchers. The Nordic countries appear in part to follow different strategies to promote gender equality and there appear to be national differences in how these issues are prioritised politically and the degree of political will to control and monitor the gender equality efforts in academia. The report provides good examples of the measures and experiences from the various countries' efforts to improve the gender balance in academia.

Despite the differences, there are very few comparative overviews and comparative studies of gender equality and gender balance in academia in the Nordic region. Nor has the issue been integrated into joint Nordic research or gender equality policy. There is also a need for research statistics that elaborate on the variations within the different sectors and the various levels of the research system in a comparative Nordic perspective.

Thus there are good reasons to establish closer cooperation between the research and gender equality sectors and the Nordic Council of Ministers in the field of gender balance and gender equality in academia. This chapter presents a variety of recommendations to ensure the future consolidation of efforts in this field. The recommendations are targeted towards the Nordic Council and the Nordic Council of Ministers, i.e. towards cooperation between the parliamentarians and between the governments. The recommendations are also directed towards NordForsk, Nordic Innovation and the Joint Committees for Nordic Research Councils (the NOS system). In addition, the Association of Nordic University Rectors Conferences (NUS) and the Nordic Association of University Administrators (NUAS) are key players in this connec- 
tion through their contacts with top-level administrators at universities and university colleges in the Nordic region.

As shown in this report, all of the Nordic countries have implemented national and local initiatives and measures to advance the research careers of women or the underrepresented gender. The objective should also be to include a gender equality perspective in all decision-making in academia and in policy development in general. This would be in keeping with several of the countries' stated objectives on the integration of a gender and gender equality perspective ("gender mainstreaming"). At the joint Nordic level there is a need for comparative studies and research on strategies and measures in the individual countries as well as for initiatives within the Nordic cooperation. While great attention has been paid to the topic of gender equality and gender balance in academia within the EU, these issues have been almost totally absent from research policy at the Nordic level, within the Nordic Council of Ministers and in the pan-Nordic research institutions. Nor has Nordic cooperation on gender equality given priority to this field.

This report clearly shows that Nordic cooperation has a need for concrete development measures with regard to policy development, research and statistics. It is therefore important to develop visions and specific future objectives at the joint Nordic level.

\subsection{Policy development}

Improved gender balance in academia is crucial for reaching national, Nordic and European research policy objectives. Gender equality and gender perspectives are needed when developing and realising research priorities. In order to achieve this, gender equality efforts in academia must become more systematic and professionalised. An exchange of experience in the Nordic region is especially important in this context and may result in new, more targeted policy-oriented measures in Nordic as well as European cooperation in the future. This will in turn help to enhance and improve the efforts in the individual countries in this field. 


\section{Recommendation 1}

The Nordic Council of Ministers (NCM) should ensure that cooperation between the research and gender equality sectors in the field of gender balance in research in the Nordic region is launched in 2013. A Nordic policy-oriented network should be established by the NCM with representatives from NordForsk, NIKK, the national research councils and the Nordic members of the European Commission's expert group for women in research (known as the Helsinki Group).

The Nordic countries should work together to develop a programme of action Gender balance is the goal - gender equality in academia in the Nordic region 2020. The programme should establish specific recruitment targets for professorships in which the proportion of women among professors in all of the Nordic countries will exceed the EU average by 2020. For the proportion of women in rector positions, the target should be at least 40 per cent by 2020 . The programme of action will also help to enhance the expertise of leaders at universities and university colleges in the area of gender balance in academia.

The programme of action should include a provision that all public research funding organisations in the Nordic countries and at the joint Nordic level should introduce a clear, consistent system for reporting on the progress made in improving the gender balance in academia in the Nordic region.

\subsection{Research}

The Nordic region still largely lacks research-based knowledge about gender balance in academia. A sound knowledge-base is needed in order to conduct effective policy, especially for implementing long-term measures. Quantitative studies of women's and men's participation in research should be supplemented by qualitative studies of the factors that influence participation and progress in research. It is vital both to develop research on the gender barriers and gender dynamics in academia within the individual Nordic countries and to establish comparative research projects between the Nordic countries - and between the Nordic region and other European countries. Differences and similarities between the Nordic countries present interesting challenges for comparative studies. 
Examples of additional knowledge needs in the field, both nationally and as joint Nordic research initiatives, include:

- Recruitment, advancement and mobility in research careers in a gender equality perspective.

- Gender balance in research leadership and governance bodies.

- Gender balance at independent research institutes and within trade and industry.

- Research funding and gender.

- Academic culture and the organisation of funding in a gender and gender equality perspective.

- Potential gender policy ramifications of new research policy trends.

- Working environment studies in a gender equality perspective.

- Combining a research career and family by women and men researchers; time-use studies in academia.

- Bibliometric studies (of publication and citation patterns) in a gender perspective.

- International research cooperation and mobility in a gender perspective.

- Gender equality efforts and measures in academia.

\section{Recommendation 2}

A Nordic research programme on gender balance in research should be established under the auspices of NordForsk and/or the Joint Committees for Nordic Research Councils (NOS) with funding from the Nordic Council of Ministers and the Nordic countries.

\subsection{Statistics}

The Nordic countries have compiled statistics on education and research since the late 1960s. Statistics broken down by gender came relatively early compared with other European countries. At the same time, it is an objective to make gender-divided statistics an integral part of other statistics. For ex- 
ample, as a result of the European Commission's efforts with "She Figures", gender-divided statistics have been incorporated to a greater extent into regular R\&D statistics.

However, there are currently a number of areas that present challenges related to comparability as well as several areas about which little is known. Here it is important to view the Nordic countries as a region with great potential to develop research statistics. A "Nordic She Figures" would also be a useful tool and help to enhance the quality of the European "She Figures".

Examples of areas where there is a need for gender-divided statistics, including in a comparative perspective, are:

- Position structures in academia. These vary between countries (the same title may include persons with different qualifications; how the status of professor varies between countries).

- Research in trade and industry and at independent research institutes.

- Development of indicators on researcher mobility, especially between countries and sectors.

- Conditions for part-time and temporary positions.

- Research funding; funding sources for positions.

- Bibliometric studies.

- Technology transfer, innovation; patents.

- Time-use studies.

\section{Recommendation 3}

The Nordic Council of Ministers should launch a pilot project that systematically develops joint Nordic statistics on research and education in the field of gender balance in academia. 



\section{References}

Andersen, Heine \& Inge Henningsen (2009): Forskningsråd i Danmark: mangfoldighet og universalisme? En analyse av forskningsrådenes bevillingspraksis i perioden 2001-2006 [Research councils in Denmark: diversity and universalism?]. Københavns Universitet, København.

Aukland, Kristin (2012): Likestillingstiltak i forskningssektoren: En kartlegging av BALANSE-relaterte initiativ for Forskningsrådet. [Gender equality measures in the research sector: a mapping of BALANSE-related initiatives for the Norwegian Research Council]. KILDEN Informasjonssenter for kjønnsforskning, Oslo.

Bergqvist, Christina et al. (2009): Likestilte demokratier? Kjønn og politikk i Norden [Equal democracies? Gender and politics in the Nordic countries]. Universitetsforlaget, Oslo.

Egeland, Cathrine \& Ann Cecilie Bergene (2012): Tidsbruk, arbeidstid og tidskonflikt i den norske universitets- og høgskolesektoren. [Time use, working time and conflict of time in academia in Norway]. Arbeidsforskningsinstituttet, Oslo.

European Commission (2004): Gender and Excellence in the Making. Official Publications of the European Communities Luxembourg.

European Commission (2009): The Gender Challenge in Research Funding. Mapping the European national scenes. Official Publications of the European Communities Luxembourg.

European Commission (2010a): Marchetti, Marina \& Tiia Raudma, eds. Stocktaking 10 years of "Women in Science" policy by the European Commission 19992009. Directorate-General for Research.

European Commission (2010b): Meta-analysis of gender and science research. Directorate-General for Research.

European Commission (2012): Communication from the Commission to the European Parliament, the Council, the European Economic and Social Committee and the Committee of the Regions: A Reinforced European Research Area Partnership for Excellence and Growth. COM(2012) 392.

European Commission (2012): She Figures 2012. Statistics and Indicators on Gender Equality in Science. Official Publications of the European Communities Luxembourg

Heikkilä, Mia \& Anneli Häyrén Weinestål (2010): Kartläggning och analys av jämställdhetsinsatser vid svenska universitet och högskolor 2000-2009. [Mapping and analysis of gender equality measures in academia in Sweden 2000-2009]. Delegationen för jämställdhet i högskolan.

Husu, Liisa (2010): Mot mer jämställda universitet: en internationell översikt över strategier och åtgärder. [Towards more gender-equal universities: an interna- 
tional mapping of strategies and measures]. Rapport nr. 6. Delegationen för jämställdhet i högskolan.

Løvbak, Hege E. \& Holter, Øystein G.(2012): Kjønn og karriere: En rapport om kvinners karriereutvikling med utgangspunkt i mentorprogrammet ved Universitetet i Oslo. [Gender and career: a report on women's career development with reference to the mentoring programme at the University of Oslo]. Senter for tverrfaglig kjønnsforskning, Universitetet i Oslo.

Ministry of Science, Technology and Innovation, and the Minister for Gender Equality. Ministeriet for Videnskab, Teknologi og Udvikling og Minister for Ligestilling (2006): Tænketank om flere kvinder i forskning: Alle talenter i spil - flere kvinder i forskning [ThinkTank on more women into research: All talents at stake].

Ministry of Science, Technology and Innovation. Ministeriet for Videnskab, Teknologi og Udvikling (2009): Kvindelige forskertalenter - dansk forsknings uudnyttede reserve. En kortlægning af initiativer til rekruttering og fastholdelse af kvindelige talenter i den danske forskningsverden. [Female research talents - an underutilized reserve for Danish research]. Videnskabsministeriet.

NIFU Working Paper (2012): Centres of Excellence in the Nordic Countries. A comparative study of research excellence policy and excellence centres in the Nordic countries. Working paper nr. 4. Oslo.

Niskanen, Kirsti \& Anita Nyberg (2010): Kön och makt i Norden. Del II: Sammanfattande diskussion och analys [Gender and power in the Nordic countries. Part II: Summarising discussion and analysis]. TemaNord 2010:525, 34-35.

Nora: Nordic Journal for Women's Studies (2001): $\mathrm{nr}$ 3. Special issue on Gender in Academia.

NordForsk magazine 2012.

Nordic Academy for Advanced Studies - NorFa (2002): Women in Academia - a Nordic perspective. Proceedings from the conference in Oslo 7th-9th May 2001.

Norwegian Research Council. Norges forskningsråd (2007): Forskningsrådets policy for likestilling og kjønnsperspektiver i forskning 2007-2012. [The policy for gender equality and gender perspectives in research for the Norwegian Research Council 2007-2012]. Norges forskningsråd, Oslo.

Norwegian Research Council. Norges forskningsråd (2009): Likestilling i forskning - hva fungerer? En analyse av tildelingsprosessene i Forskningsrådets kvalitetssatsinger YFF, SFF og SFI. [Gender equality in research - what works? An analysis of the allocation of research funding in the excellence initiatives of the Norwegian Research Council]. Norges forskningsråd, Oslo.

NOU 2011: 18. Struktur for likestilling [Structure for Gender Equality].

Redegørelse 2009/Perspektiv- og handlingsplan 2010: Afgivet til Folketinget af Minister for Ligestilling Lykke Friis den 14. april 2010. [Annual report 2009/Plan of perspectives and action 2010]. Minister for Ligestilling.

Rustad, Linda M. \& Marte Ericson Ryste, eds. (2010): Talent at Stake: Changing the Culture of Research - Gender-sensitive leadership. Komité for integreringstiltak - Kvinner i forskning 2007-2010. 
Sandström, Ulf, Agnes Wold, Birgitta Jordansson, Björn Ohlsson, Åsa Smedberg (2010): Hans Excellens - om miljardsatsningarna på starka forskningsmiljöer [His Excellence - Allocation of resources on strong research units]. Slutrapport. Delegationen för jämställdhet i högskolan.

SIU Report Series (2011), Report 02: International Mobility among PhD Candidates at Norwegian Higher Education Institutions. Norwegian Centre for International Cooperation in Higher Education.

SOU 1996: 28. Ståhle, Bertel, Det forskningspolitiska landskapet i Norden på 1990talet [The research policy landscape in the Nordic region in the 1990s].

SOU 2011: 1. Slutrapport. Delegationen för jämställdhet i högskolan [Final report. The delegation for gender equality in institutions of higher education].

Ministry for Social Affairs and Health. Statsrådets redogörelse om jämställdheten mellan kvinnor och män [Report on Gender Equality]. Social- och hälsovårdsministeriet, Publikationer 2010: 9.

Swedish National Agency for Higher Education. Högskoleverket (2008): Doktorandspegeln 2008 [Ph.D. students in the mirror]. Högskoleverkets rapportserie 2008:23 R.

Vabø, Agnete \& Inge Ramberg (2009): Arbeidsvilkår i norsk forskning [Working conditions in Norwegian research]. Rapport 9. NIFU STEP, Oslo.

Vabø Agnete, Hebe Gunnes, Cathrine Tømte, Ann Cecilie Bergene \& Cathrine Egeland (2012): Kvinner og menns karriereløp i norsk forskning: En tilstandsrapport [Women's and men's career path in Norwegian research]. Rapport 9. NIFU, Oslo.

World Economic Forum Gender Gap Reports 2011-2012. 



\section{Sammendrag}

Kjønnsbalanse i akademia utgjør globalt en viktig forskningspolitisk problematikk som hittil ikke har vært utviklet eller debattert på samnordisk plan. Denne rapporten forsøker å løfte frem disse spørsmålene ved å sammenstille utviklingen i de nordiske landene innen lovgivning, statistikk og politikk på feltet. Rapporten gir eksempler på vellykkete virkemidler og tiltak som har forbedret kjønnsbalansen i akademia i landene. Rapporten belyser noen aktuelle forskningspolitiske spørsmål og utfordringer som er viktige å analysere i et kjønns- og likestillingsperspektiv.

I dag er nær 80 prosent av alle professorer i Norden menn. Kjønnsfordelingen er svært skjev mellom de ulike fagområdene, og den største ubalansen finner vi innen naturvitenskap og teknologi. De nordiske landene ser ut til å følge dels ulike strategier for å fremme kjønnsbalanse, og det er interessante forskjeller mellom landene når det gjelder kjønnssammensetning blant forskere. Den politiske prioriteringen av spørsmålene og den politiske viljen til styring og overvåking av likestillingsarbeidet $\mathrm{i}$ akademia, varierer også mellom landene.

I de nordiske landene har likestilling i akademia vært på den forskningspolitiske agendaen lenger enn i de fleste andre europeiske land, dvs. siden 1970- og 1980-tallet. Ved mange av universitetene og høgskolene i Norden, og i de nasjonale forskningsrådene, har det vært organisert likestillingsarbeid og blitt gjennomført tiltak for å bedre kjønnsbalansen i forskning $\mathrm{i}$ flere tiår. Tyngdepunktet har flyttet seg fra særordninger knyttet til kvinnerekruttering og individorienterte tiltak til integrering av likestilling i ordinær virksomhet på institusjonene gjennom ulike strukturelle og institusjonelle strategier og virkemidler. Målsettingen videre bør være å inkludere likestilling i alle beslutningsprosesser i akademia og i politikkutviklingen generelt. Dette vil være i tråd med landenes uttalte ambisjon om integrering og implementering av kjønns- og likestillingsperspektiv ("gender mainstreaming").

Det forsknings- og universitetspolitiske landskapet i Norden er i forandring, noe som også har innvirkninger på likestillingsarbeidet i akademia. På 
2000-tallet har eksellenssentra og spiss- og eliteforskningsmiljøer blitt sentrale virkemidler i forskningspolitikken. Strategien er å konsentrere en større del av forskningsressursene til store enheter, programmer og eksellensmiljøer. Det er åpenbart at det trengs mer diskusjon og forskning på hvorfor eksellenssatsingene i så høy grad har blitt et forskningsinstrument som gagner mannlige forskere mer en kvinnelige, og hva som kan gjøres for å få mer kjønnsbalanserte spissmiljøer. Autonomireformen er et annet eksempel på en endring som kan få konsekvenser for likestillingsarbeidet. I takt med økt selvstyring og autonomi for universiteter og høgskoler er det en mulighet for at institusjonene selv i større grad må ta ansvar for likestillingsarbeidet uten et nasjonalt påtrykk som vi hittil har hatt lang tradisjon for i Norden. Disse forandringene i forsknings- og universitetspolitikken må analyseres og evalueres ut fra de konsekvenser som tiltakene har for kjønnsbalansen i forskersamfunnet.

Når det gjelder satsinger for å øke andelen kvinner i forskningsverdenen, er det ikke nødvendigvis alltid i Norden vi finner de beste eksemplene. Europakommisjonen har siden slutten av 1990-tallet satt fokus på kvinner i forskning og likestillingsspørsmål, og har betont at kjønnsperspektiver i forskningspolitikk betyr både økt likestilling i akademia og at forskningens innhold endres. I motsetning til den oppmerksomhet temaet likestilling og kjønnsbalanse i akademia har hatt i EU, har disse spørsmålene vært så godt som helt fraværende i forskningspolitikken innenfor Nordisk ministerråd og de samnordiske forskningsinstitusjonene. Heller ikke det nordiske likestillingssamarbeidet har prioritert dette feltet.

Til tross for at det eksisterer store forskjeller mellom de ulike landene i Norden, er komparative kartlegginger og sammenlignende forskning om kjønnsbalanse i akademia i Norden svært fa. Det finnes derfor gode begrunnelser for å etablere og utvikle nordisk samarbeid på dette feltet. Rapporten munner ut i en rekke anbefalinger rettet til beslutningstakere og andre relevante aktører i Nordisk råd, Nordisk ministerråd og andre samnordiske institusjoner med formål å sikre en konsolidering av feltet kjønnsbalanse i akademia som et samlet policy- og forskningsfelt i Norden. Anbefalingene tar sikte på et nordisk handlingsprogram med bl.a. konkrete rekrutteringsmål for toppstillinger i akademia, etablering av et nordisk policyrettet nettverk, et nordisk forskningsprogram og et pilotprosjekt i nordisk utdannings- og forskningsstatistikk. 


\section{Attachments}

Figure 1.1. Proportion of women and men at various rungs of the academic career ladder in Denmark 2009/2010

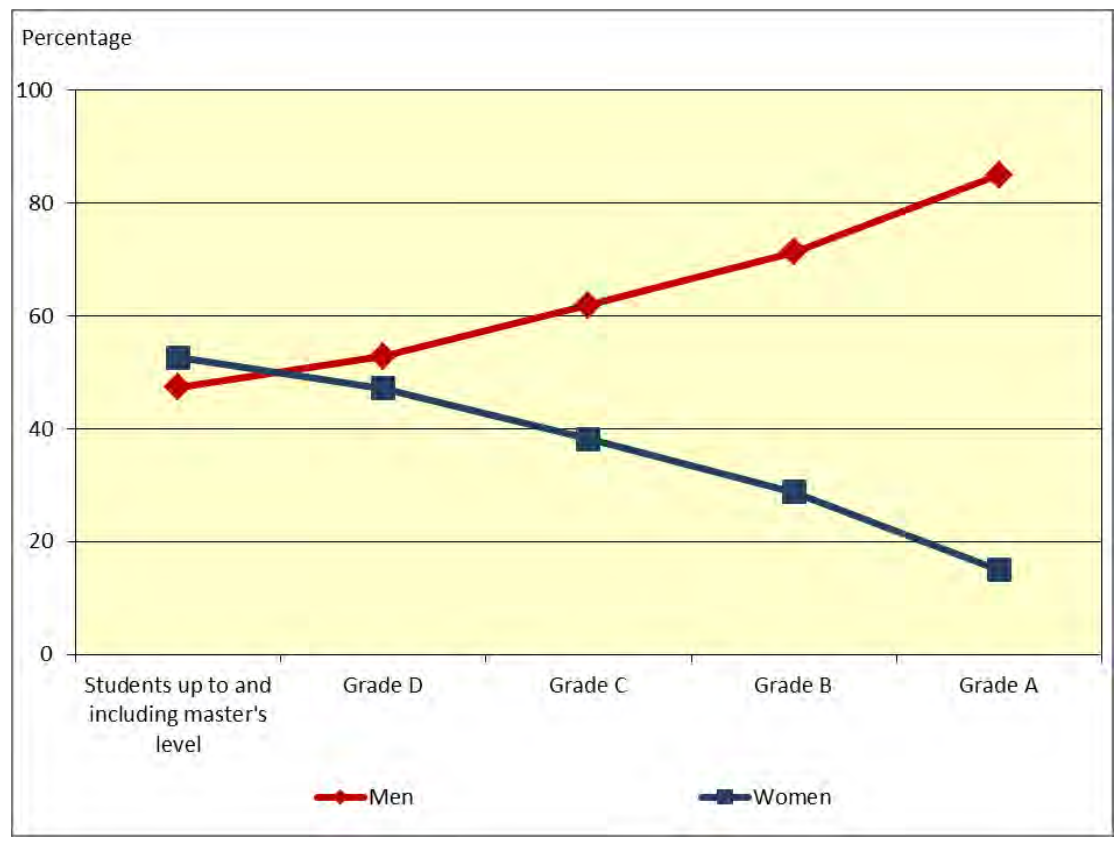

Sources: She Figures 2012 and national statistics producers. 
Figure 1.2. Proportion of women and men at various rungs of the academic career ladder in Finland 2010*

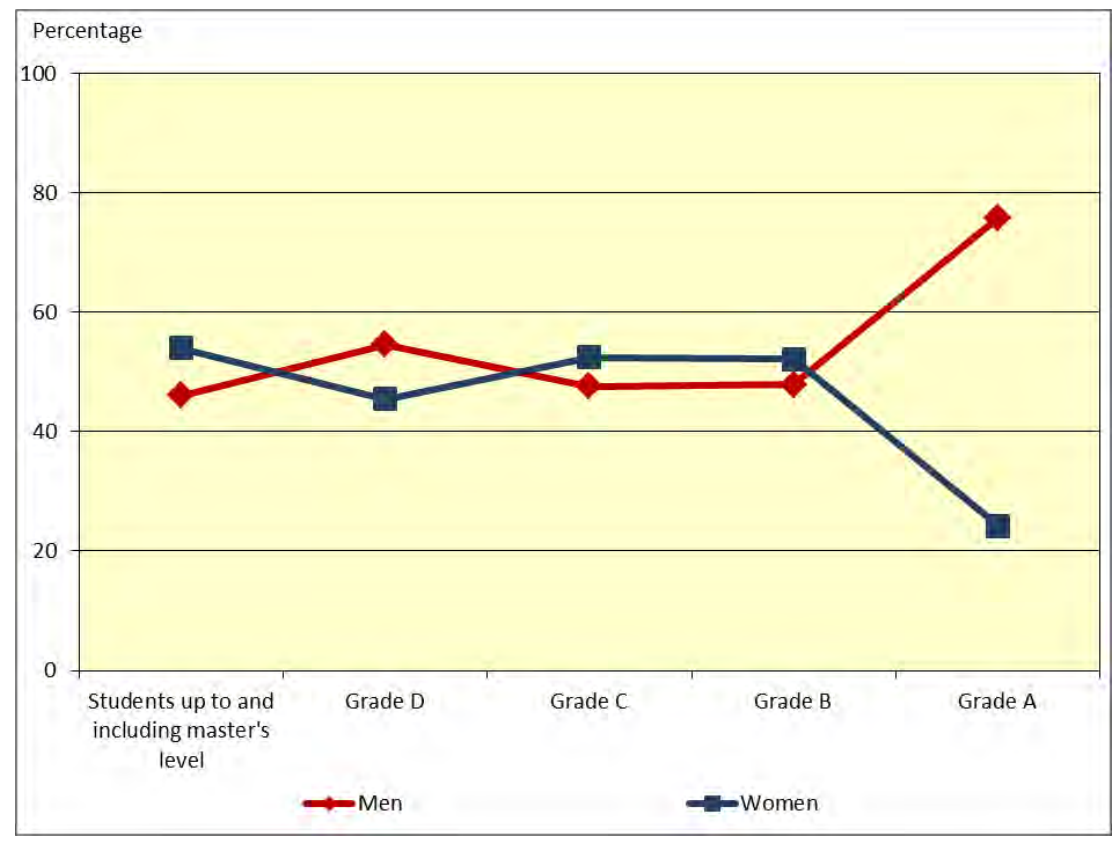

*Statistics for Finland include administrative positions, which affect the gender distribution for the individual categories in the figure.

Sources: She Figures 2012 and national statistics producers. 
Figure 1.3. Proportion of women and men at various rungs of the academic career ladder in Iceland 2010*

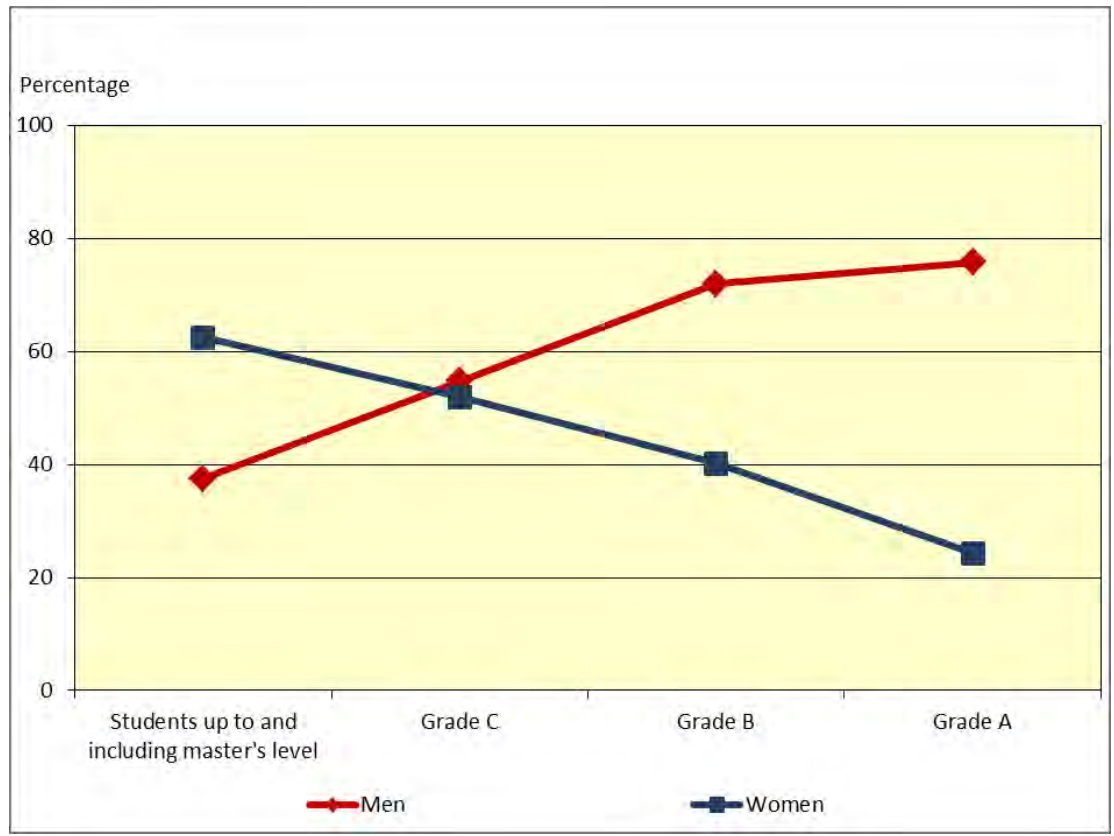

*Many people in Iceland complete a doctoral degree abroad, which is not shown in the statistics. Iceland does not report data for grade D to She Figures.

Sources: She Figures 2012 and national statistics producers. 
Figure 1.4. Proportion of women and men at various rungs of the academic career ladder in Norway 2010

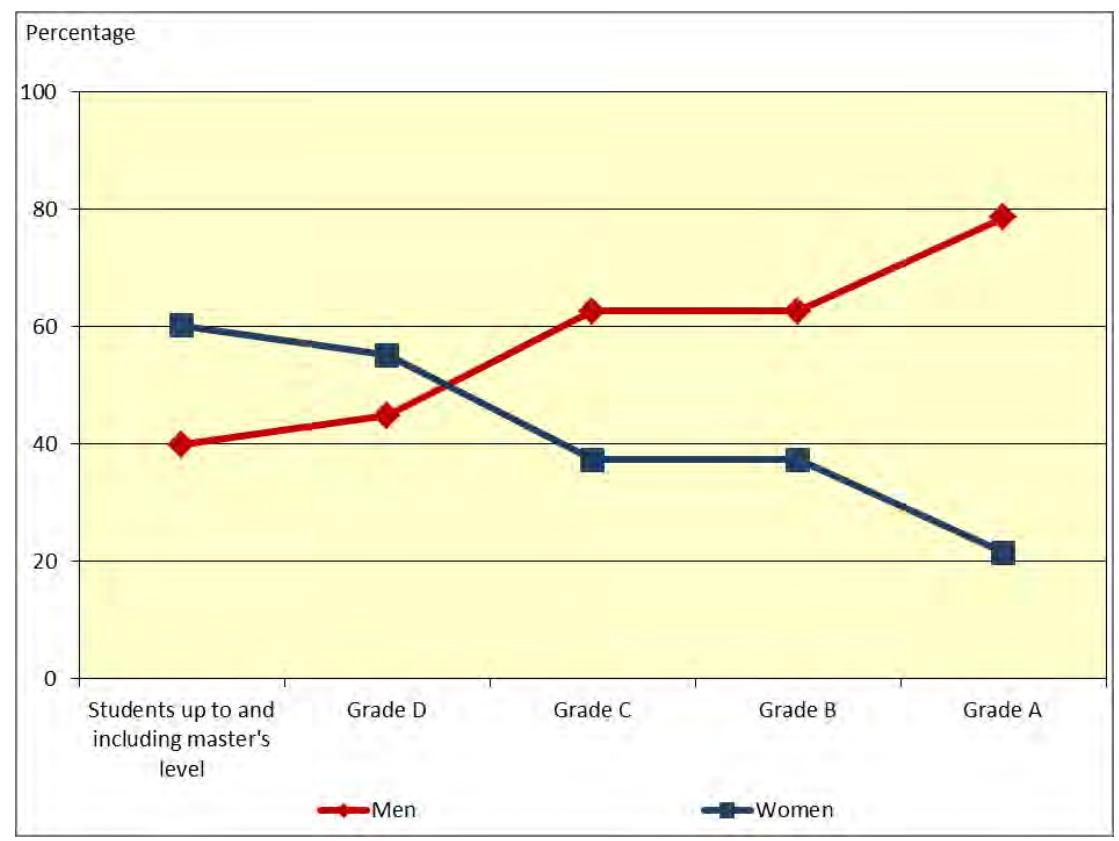

Sources: She Figures 2012 and national statistics producers. 
Figure 1.5. Proportion of women and men at various rungs of the academic career ladder in Sweden 2010*

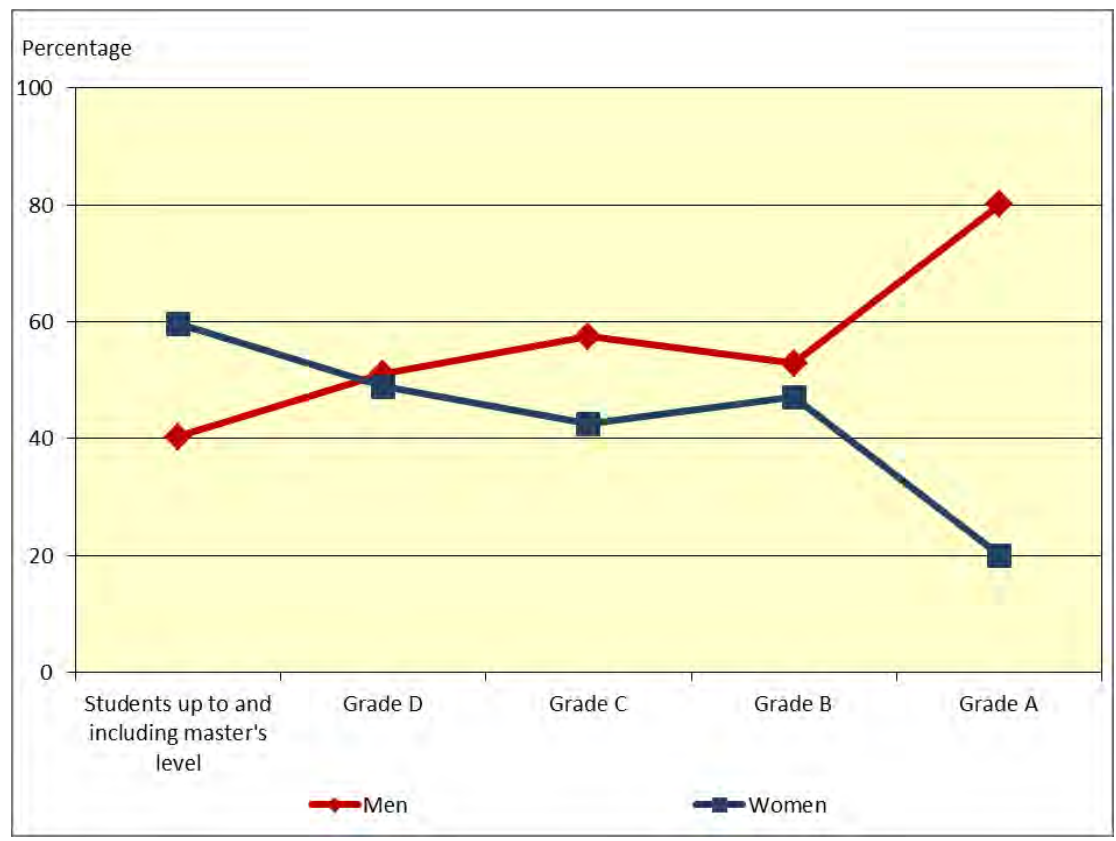

*In Sweden, the percentage of women in grade B is greater than in grade $\mathrm{C}$. In this figure, grade $\mathrm{B}$ includes lecturers, adjuncts, visiting and hourly instructors, other research and teaching staff, as well as administrative and technical staff. The administrative staff represents a large share of the total, and women comprise 75 per cent of this category.

Sources: She Figures 2012 and national statistics producers. 
Nordic Council of Ministers

Ved Stranden 18

DK-1061 Copenhagen K

www.norden.org

\section{The Nordic region - a step closer to gender balance in research?}

Nearly 80 per cent of all professors in the Nordic region are men. Gender balance in academia is therefore an important research policy issue. Hitherto it has been scarcely debated on a joint Nordic level. This report shows the status and the development in the field. The report gives examples of successful practices and highlights research policy challenges that are important to analyse in a gender and equality perspective.

Given the lack of comparative investigations and research on the gender balance in academia in the Nordic region, there is a need to develop Nordic cooperation in this field. The report concludes with a number of recommendations in order to consolidate the issue of gender balance in academia as a joint policy- and research field in the Nordic region.

TemaNord 2013:544

ISBN 978-92-893-2568-4

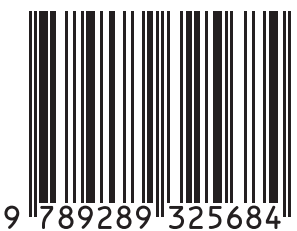

